\title{
Articles
}

\section{Strengthening European Union Democratic Accountability Through National and Treaty-Based Pre-Legislative Controls}

\author{
By Özlem Ülgen ${ }^{*}$
}

\begin{abstract}
This article considers whether greater accountability for EU supranational decision-making can be achieved through a combination of member states' legislative processes and EU treaty-based mechanisms. The EU is formed by member states' national consent through treaty ratification and a system of domestic pre-legislative controls on consentparliamentary approval, public consultation and referendum-which operates to limit the nature and extent of EU law. Using the UK as an example to compare with other member states, the article contends that such domestic controls are prerequisites to national incorporation of EU law and strengthen democratic accountability. Consent alone, however, does not provide an adequate basis for accountability of supranational decisions; EU constitutional principles of citizenship, democracy, and political rights illustrate how the EU fulfills a role as protector of rights. The article further argues that the EU's protector role represents partial legitimacy and accountability for supranational decisions. Greater legitimacy and accountability derives from national parliaments' pre-legislative controls under EU law-scrutinizing legislation, monitoring subsidiarity, and exercising veto powers. The article concludes that if these controls are exercised properly, they represent powerful accountability mechanisms.
\end{abstract}

\footnotetext{
* Senior Lecturer in Law, School of Law, Birmingham City University, UK: ozlem.ulgen@bcu.ac.uk. The author provided written and oral evidence to the UK Government's 2014 Review of Balance of Competences between the UK and EU: Subsidiarity and Proportionality (final ministerial report to Parliament, December 2014). The author would like to thank Martin Trybus for his helpful comments on an earlier draft.
} 


\section{A. Introduction}

How often do politicians point to the European Union's "democratic deficit"? In evaluating the press coverage, the media uses this phrase far too often as a slogan to galvanize popular sentiment for national retrenchment and reassertion of sovereignty. After forty years of membership, the United Kingdom ("UK") is now set to hold a referendum on European Union ("EU") membership. On 5 July 2013, the UK parliament voted in favor of introducing legislation to allow a national referendum to take place before $2017 .{ }^{1}$ Feeling the brunt of financial cuts, strict EU bailout terms, and the imposition of new regulatory requirements, Greece, Spain, Portugal, Italy, and Cyprus have mooted the possibility of pulling out of the eurozone to save their respective economies. In such a climate, the doctrine of supremacy, under which EU law prevails over member states' national laws, is a predictable target for the "democratic deficit" slogan. Politicians, however, have a responsibility to be properly informed so that they can represent and constructively engage the electorate. Simply stating that EU law prevails over national laws misrepresents member states' consent and involvement in decision-making processes. It does not take into account three features of democratic accountability under EU law: (1) The consent of member states; (2) constitutional principles of citizenship, rights, democracy, and the protector role of EU institutions; and (3) the role of national parliaments.

This article considers how the EU is formed by member states' national consent through treaty ratification and a system of domestic pre-legislative controls on consentparliamentary approval, public consultation and referendum-which operates to limit the nature and extent of EU law. Using the UK as an example to compare with other member states, it contends that such domestic controls are prerequisites to national incorporation of EU law and strengthen democratic accountability. Consent alone, however, does not provide an adequate basis for accountability of supranational decisions; EU constitutional principles of citizenship, democracy, and political rights illustrate how the EU fulfills a role as protector of rights. It is further argued that the EU's protector role represents partial legitimacy and accountability for supranational decisions. Greater legitimacy and accountability derives from national parliaments' pre-legislative controls under EU lawscrutinizing legislation, monitoring subsidiarity, and exercising veto powers. The article concludes that if these controls are exercised properly, they represent powerful accountability mechanisms.

\footnotetext{
15 July 2013, 565 PARL. DeB., H.C. (2013) 1169-1246 (U.K.).
} 


\section{B. National Consent}

Some scholars argue that because the EU is established by member states, which in turn are composed of democratically elected governments, their consent through treaty ratification provides legitimacy for decisions at the supranational level. ${ }^{2}$ National courts, in considering the impact of EU law on domestic law, have also pointed to the decisive role of member states as sovereign entities with ultimate authority to limit their own sovereignty. ${ }^{3}$ This state-centric view conforms to traditional international law on international organizations, which posits that national consent forms the basis of an organization's existence, mandate, and functions. ${ }^{4}$ State sovereignty and the capacity to enter into treaty relations are foundational principles of modern international law. It is precisely by focusing on the state-centric view that one can begin to understand how national consent forms part of the EU's legitimacy and accountability.

\section{National Consent by Treaty Ratification}

Formed out of the carnage and troubles of World War II, the founding aim of the EU was to pool continental states' coal and steel, atomic energy, and economic resources in order to establish conditions for peace, stability, and economic prosperity, thereby avoiding conflict. ${ }^{5}$ Since establishing this laudable aim, the EU has become more than a continental economic cooperation zone. From the introduction of the euro in 2002 to the consolidation of EU competences under the Treaty of Lisbon, which came into force in 2009, the EU now operates as a supranational organization representing twenty-eight member states in economic, cultural, social, environmental, and political affairs. ${ }^{6}$ National

\footnotetext{
${ }^{2}$ Renaud Dehousse, Institutional Reform in the European Community: Are There Alternatives to the Majoritarian Avenue? (European Univ. Inst., EUI Working Paper RSC 95/4, 1995).

${ }^{3}$ See 89 BverfGE 155; see also R v. Secretary of State for Transport, ex parte Factortame Ltd. No.2 [1991] 1 A.C. $603,659$.

${ }^{4}$ INTERNATIONAL ORgANIZATIONS (Jan Klabbers ed., 2005).

${ }^{5}$ See Preamble to 1957 Treaty of Rome Establishing the European Economic Community, Mar. 25, 1957; see also DeReK URWIN, THe COMMUNITY of EUROPE: A HISTORY of EUROPEAN INTEGRATION (1995); see also John PINDER \& SIMON UsherWOod, THE EUROPEAN UnION: A Very SHORT INTROduction (2013); see also JOHN PINDER, THe BUILDING of the EUROPEAN UNION (1998).

${ }^{6}$ See Consolidated Version of the Treaty on the Functioning of the European Union arts. 119, 140, May 9, 2008, 2008 O.J. (C 115) 47 [hereinafter TFEU]; see also TFEU art. 20; see also Treaty on European Union arts. 4-6, Oct. 26, 2012, 2012 (C 326) [hereinafter TEU]; see also TFEU arts. 4-6 (describing expansion of EU shared and complementary competencies-health protection, education, culture, development cooperation, environmental protection, consumer protection]); see also Single Market Act: Twelve Levers to Boost Growth and Strengthen Confidence, Working Together to Create New Growth, COM (2011) 206 final (Apr. 13, 2011); see also Paul Craig, The Lisbon Treaty: Process, Architecture and Substance, 33 EUR. L. REV. 137 (2008).
} 
consent has been a key feature along this evolutionary path. All member states have, in one form or another, agreed and consented to join the EU, leading to the formal process of ratifying EU treaties. Giandomenico Majone refers to this as "derived legitimacy." ${ }^{7}$ One can see this from the start of the EU as a single market with a single currency to the creation of a separate legal order with a political and cultural vision.

Prior to membership in the EU, each candidate state must ensure compliance with the acquis communautaire ("acquis") and must bring its national laws into compliance with EU law to meet membership criteria. A process of dialogue and negotiation takes place between the state and the EU, sometimes leading to opt-outs or derogations from certain treaty provisions. The candidate state has the responsibility to implement legislation and amend laws to be in compliance with the acquis. Failure to bring national law into compliance with the acquis has been referred to as a "deficit in the political process." ${ }^{8}$ Consultations with relevant national stakeholders on proposed EU legislation must take place to raise any potential conflict with existing domestic law and practice. These consultations allow individuals and groups to hold their government accountable during negotiations with the EU. Assuming the acquis is implemented, the next stage of consent is formal signature and ratification of the EU treaties. The formal act of signature and ratification represents a legal commitment, and under the principle of pacta sunt servanda, the member state is bound to act in good faith in implementing its treaty obligations. ${ }^{9}$ This principle is recognized in Article 4(3) Treaty on European Union ("TEU"), also referred to as the fidelity clause. ${ }^{10}$

EU treaties are international treaties that require domestic transposition before taking effect. This may take one of two forms: automatic incorporation or incorporation by domestic legislation. In monist legal systems, once the treaty is ratified, it has automatic effect in domestic law without necessitating incorporating legislation. Thus, Article 93 of the Dutch Constitution provides that international law may have direct effect and take

\footnotetext{
${ }^{7}$ Giandomenico Majone, Europe's 'Democratic Deficit': The Question of Standards, 4(1) EUR. L.J. 5, 12 (1998).

${ }^{8}$ For example, the Polish parliament's failure to amend the constitution to implement Council Framework Decision 2002/584 of 13 June 2002 on the European Arrest Warrant, which formed part of the acquis at the point of accession; see Darinka Piqani, Arguments for a Holistic Approach in European Constitutionalism: What Role for National Institutions in Avoiding Constitutional Conflicts Between National Constitutions and EU Law, 8(3) EUR. CONST. L. ReV. 493, 503 (2012).

${ }^{9}$ See Vienna Convention on the Law of Treaties art. 26, May 23, 1969, 1155 U.N.T.S. 331; see also ARNOLD MCNAIR, The LAW of TREATIES (1961).

${ }^{10}$ See TEU art. 4(3); Case C-266/03, Commission v. Luxembourg, 2005 E.C.R. I-0000 (interpreting Article 4(3) as entailing enforceable substantive and procedural obligations).
} 
precedence over Dutch law. ${ }^{11}$ Under Article 94, some rules of international law take precedence over all domestic law, and any national statutory provisions that are incompatible with these rules of international law are not applicable. ${ }^{12}$ These provisions taken together establish EU law's supremacy over domestic law. Indeed, the first leading case to establish the doctrine of direct effect in EU law and to refer to the EU as a "new legal order" was of Dutch origin. ${ }^{13}$ Subsequent case law supports the premise of a new legal order created by member states' consent on the basis of reciprocity. ${ }^{14}$

\section{UK Ratification and Domestic Incorporation}

In dualist legal systems, such as the UK, a ratified treaty must be incorporated into domestic law by implementing legislation. Under UK law, a treaty takes effect once an act of parliament incorporates it into domestic law. The doctrine of parliamentary sovereignty means that parliament is free from any limitation on its power to legislate and cannot bind any future parliament, so one parliament could introduce new legislation and another could repeal it. Parliament is supreme in its law-making authority, potentially placing UK constitutional law in direct conflict with the supremacy of EU law. But parliamentary sovereignty remains a constitutional convention rather than a statutory provision, allowing flexibility when incorporating EU law. Thus, the European Community ("EC") treaties were incorporated through the European Communities Act 1972 ("the Communities Act") by simple assent, involving agreement to apply the treaties without having to incorporate each treaty provision. This avoided potential conflict and implied repeal by any subsequent statute.

The Communities Act requires that: (1) Any future act of parliament to be construed in line with EU law; ${ }^{15}$ and (2) UK courts determine the meaning or effect of any treaty provision or EU instrument in accordance with principles set out by the European Court of Justice ("CJEU"), as well as following its decisions. ${ }^{16}$ Taken together, these provisions mean CJEU decisions on supremacy in Costa v. ENEL, Internationale Handelsgesellschaft, and

${ }^{11} \mathrm{Gw}$. [Constitution], art. 93 (Neth.).

${ }^{12}$ Gw. [Constitution], art. 94 (Neth.).

${ }^{13}$ See Case 26/62, Van Gend en Loos v. Nederlandse Administratie der Belastingen, 1963 E.C.R. 1.

${ }^{14}$ See Case 6/64, Costa v. ENEL, 1964 E.C.R. 585; see also Case 11/70, Internationale Handelsgesellschaft, 1970 E.C.R. 1126.

${ }^{15}$ The European Communities Act, 1972, c. 68, § 2(4) (U.K.) [hereinafter “The Communities Act"].

${ }^{16}$ See id. c. $68, \S \S 3(1)-(2)$. 
Simmenthal bind the UK. ${ }^{17}$ This is supported by UK case law. ${ }^{18}$ The rule of construction has been interpreted to oblige UK courts to adhere to supremacy where there is conflict between EU law and any former or subsequent statute. ${ }^{19}$ The Communities Act has also been identified as a "constitutional statute" not subject to implied repeal. ${ }^{20}$ In this sense, the UK has maintained its dualism and parliamentary sovereignty by choosing to designate the incorporating legislation as part of a constitutional hierarchy. Parliament consents to the limitation of its own legislative authority by becoming a part of a new legal order under the EU. ${ }^{21}$ In the words of Lord Bridge, "[W] hatever limitation of its sovereignty Parliament accepted when it enacted the European Communities Act was entirely voluntary." 22

A peculiarity of UK constitutional law makes it questionable whether, prior to any act incorporating an international treaty, there is democratic accountability. Who decides to ratify the treaty in the first place? The Crown-as represented by the government in parliament-has prerogative power to ratify international treaties and it is a nonjusticiable foreign affairs matter, meaning it is not subject to review by the courts. Technically, it also does not require parliamentary approval. ${ }^{23}$ Still, a precedent was set in $R v$. Secretary of State Foreign and Commonwealth Affairs, ex $p$ Rees-Mogg ${ }^{24}$ when the court decided it could consider the government's exercise of prerogative powers in relation to ratifying the Maastricht Treaty. The case failed on its merits due to the lack of ability to surrender or transfer prerogative powers by the UK government, and judicial scrutiny of the original power was deemed inadmissible. ${ }^{25}$ Nevertheless, it does represent

\footnotetext{
${ }^{17}$ See Costa at 585; see generally Internationale Handelsgesellschaft.

${ }^{18}$ See Macarthys Ltd v. Smith [1981] Q.B. 199; see also Garland v. British Rail Engineering [1982] 2 All E.R 402; see also Marshall v. Southampton and South West Hampshire Area Authority [1986] Q.B. 401; see also R v. Secretary of State for Transport, ex parte Factortame Ltd. [1989] 2 All E.R. 692; see also Thoburn v. Sunderland City Council [2002] EWHC 195.

${ }^{19}$ See the Court of Appeal's position in relation to a statute preceding the Communities Act in Macarthys Ltd v. Smith [1981] Q.B. 199 and the House of Lord's position in relation to a statute subsequent to the Communities Act in R v. Secretary of State for Transport, ex parte Factortame Ltd. [1989] 2 All E.R. 692.

${ }^{20}$ See Thoburn v. Sunderland City Council [2002] EWHC 195, 60-62.

${ }^{21}$ See T.R.S. Allan, Parliamentary Sovereignty: Law, Politics and Revolution, 113 L.Q. REV. 443 (1997); see also H.W.R. Wade, Sovereignty: Revolution or Evolution?, 112 L.Q. REv. 568 (1996).

${ }^{22}$ See R v. Secretary of State for Transport, ex parte Factortame Ltd. No.2 [1991] 1 A.C. 603, 659.

${ }^{23}$ See Attorney General for Canada v. Attorney General for Ontario [1937] A.C. 326.

${ }^{24}$ See R v. Secretary of State Foreign and Commonwealth Affairs, ex parte Rees-Mogg [1994] 2 W.L.R. 115.

${ }^{25}$ See id. at 568-71.
} 
concern about unfettered use of prerogative powers, and attempts have been made to codify their use in legislation. On 3 March 1999, the government proposed the Crown Prerogatives Bill to control the existence, extent, and exercise of the prerogative to sign treaties. ${ }^{26}$ During parliamentary debates preceding the invasion of Iraq in March 2003, members of parliament ("MPs") proposed formalization of prior parliamentary consent. ${ }^{27}$ In 2004, the Public Administration Select Committee advised that the prerogatives to sign treaties and to wage war needed statutory authority. ${ }^{28}$ In August 2013, parliament voted against military action in Syria, making it increasingly difficult for the government to override the democratic will of the people. ${ }^{29}$ The Prime Minister declared he would not override parliament's decision by exercising the prerogative power. ${ }^{30}$ Although proposals for statutory codification of prerogative powers have not been pursued, domestic controls exist in the UK to potentially limit or exclude future EU legislation.

\section{Pre-Legislative Domestic Controls on Consent}

Each member state has domestic pre-legislative controls on consent operating to limit the nature and extent of EU law. These vary and include public consultation, legislative approval, and-the most progressive form of direct democracy-referendum. ${ }^{31}$ Judicial

${ }^{26}$ Crown Prerogatives (Parliamentary Control) Bill, HC Parliamentary Business, Mar. 3, 1999, available at http: //www.publications.parliament.uk/pa/cm199899/cmbills/055/1999055.htm.

${ }^{27}$ Tam Dalyell MP introduced a private member's bill, the Military Action Against Iraq (Parliamentary Approval) Bill, which received its first formal reading on 26 January 1999 but failed to progress due to the Queen's refusal to grant consent for debate on the prerogative power to wage war. The bill can be seen at http://www.parliament.the-stationery-office.co.uk/pa/cm199899/cmbills/035/1999035.htm. See also 13 Feb. 2003, 339 PARL. Deb., H.C. (2003) 1056-73 (UK); see also 10 Mar. 2003, 401 PARL. DeB., H.C. (2003) 32, 35, 38; see also 17 Mar. 2003, 401 PARL. DEB., H.C. (2003) 703-23.

${ }^{28}$ House of Commons Public Administration Select Committee, taming the Prerogative: Strengthening Ministerial Accountability to Parliament, Fourth Report of Session 2003-04, H.C. 422.

${ }^{29}$ N. Watt, R. Mason \& N. Hopkins, MPs force Cameron to Rule Out British Assault on Syria, ThE GUARDIAN (Aug. 30, 2013), http://www.theguardian.com/politics/2013/aug/30/cameron-mps-syria (showing how many MPs reported acting on overwhelming opposition from their constituents expressed via Twitter, emails and meetings).

30 See 29 Aug. 2013, 556 PARL. DeB., H.C. (2013) 1425-1556.

${ }^{31}$ For an example, see Irish Supreme Court, Case 1986 No. 12036P, Crotty v. An Taoiseach, [1987] I.R. 713, establishing the constitutional practice of referendums for EU treaty reforms. Section 20(2) of the Danish Constitution allows for transfer of powers to the EU by statute adopted by a five-sixths parliamentary majority or simple majority public vote. Ireland, Denmark, and the UK are the only member states constitutionally requiring a referendum. Referendums in France, the Netherlands, Spain, and Luxembourg in 2005 on the Constitutional Treaty were not constitutionally required. See Fernando Mendez \& Mario Mendez, Referendums and European Integration: Beyond the Lisbon Vote, PUBLIC LAW 223 (2010). 
review is also a mechanism to check executive decision-making power and scrutinize the constitutionality of legislative acts. ${ }^{32}$ Still, as seen through the Lisbon decisions of member states' domestic courts, judicial review is not necessarily a pre-legislative control preventing a decision and, in some cases, operates as a post-legislative check endorsing a decision rather than nullifying it. ${ }^{33}$ Even where there is separation of powers between institutions of the state, judicial review may hinder democratic accountability by limiting the types of individuals who can bring judicial review claims. ${ }^{34}$ The pre-legislative controls which allow for public involvement either through representative or direct democracy offer the clearest indication of democratic accountability for national consent to EU decisions.

Member states have used these controls where situations involved membership enlargement or major treaty revisions. ${ }^{35}$ While they represent a form of democratic accountability for EU decision-making, it is important to recognize their limitations. First, not all member states have the full range of domestic controls leading up to referendum. Although this may result in different levels of democratic accountability across the EU, it is intrinsic to each member state's constitutional set up-a fact explicitly recognized under the national identity clause in Article 4(2) TEU and other provisions respecting constitutional requirements. ${ }^{36}$ Second, the exercise of domestic controls may be subject to conditions-such as a set number of votes in parliament-which may not be satisfied. ${ }^{37}$

\footnotetext{
${ }^{32}$ See French Conseil Constitutionnel [Constitutional Court] reviews of the Constitutional Treaty and the Lisbon Treaty under Article 54 of the French Constitution: Conseil constitutionnel [CC] [Constitutional Court] decision No. 2004-505DC, Nov. 19, 2004 (Fr.); Conseil constitutionnel [CC] [Constitutional Court] decision No. 2007-560DC, Dec. 20, 2007. See also Ústavní soud České republiky dne 26.11.2008 (ÚS) [Constitutional Court] [Decision of the Constitutional Court of Nov. 26, 2008], sp.zn PI. Ús 19/08 (Czech); Ústavní soud České republiky dne 3.11.2009 (ÚS) [Constitutional Court] [Decision of the Constitutional Court of Nov. 3, 2009], sp.zn PI. ÚS 29/09.

${ }^{33}$ See reviews of the Hungarian Constitutional Court and Polish Constitutional Tribunal after ratification of the Lisbon Treaty: Case 143/2010 (VII. 14.) Treaty of Lisbon, Judgment of July 12, 2010; Case K 32/09 Treaty of Lisbon, judgment of Nov. 24, 2010.

34 For example, Article 93.1 no. 2 of the German Basic Law restricts complainants to the Federal Government, a Land government, or one fourth of the members of the Bundestag. The Austrian constitution restricts postlegislative complaints to individuals who can show infringement of personal rights directly affecting them.

${ }^{35}$ For example, Danish referendums on the Single European Act, the Maastricht Treaty, and the Amsterdam Treaty, and on whether Denmark should join the euro, which it has not; 2005 French and Dutch referendums voted against the Constitutional Treaty.

${ }^{36}$ See TEU arts. 6(3), 42(2); see also TFEU arts. 25, 223(1), 262, 311.

${ }^{37}$ For example, Deputies of the Austrian parliament failed to achieve the necessary one-third majority under Article 140.1 of the Austrian Federal Constitutional Law to demand a review of constitutionality of ratification of the Lisbon Treaty. After ratification they filed an individual petition, which was rejected by the Austrian
} 
Third, the existence of controls does not guarantee their use by the national bodies or institutions empowered to invoke them. This may be an issue relating to national democratic deficit. Finally, over-reliance on referendums by one member state may thwart development of the EU at the expense of all others, leaving the latter no choice but to seek changes through alternative arrangements within - or independent of-the treaty framework, ${ }^{38}$ creating a "multi-speed" Europe. ${ }^{39}$ Arguably, the UK's recent EU legislation on pre-legislative controls has made the use of alternative arrangements more likely. Compared to other member states, the UK's extensive reliance on pre-legislative controls, especially wide use of referendums, is unprecedented.

\section{German Parliamentary Responsibilities}

Germany's Basic Law does not require a referendum to take place to decide matters relating to transfer of sovereign powers, integration, or any changes to EU law. It is a constitutional requirement that sovereign powers can be transferred only by specific enactment of a statute with the Bundesrat's consent. ${ }^{40}$ This requirement is to be interpreted in such a way that it covers any amendment of texts forming the basis of European primary law which relate to: Simplified revision procedures, lacunae-filling in EU treaties, competence changes whose bases already exist but which require concretization by further legal instruments, and a change in provisions that concern decision-making procedures. ${ }^{41}$ Prior parliamentary approval of two-third votes in the Bundestag and twothird votes in the Bundesrat is required for the establishment of the EU, changes to its founding treaties, and comparable regulations that amend or supplement the Basic Law, or make such amendments or supplements possible. ${ }^{42}$

In relation to ratification of the Maastricht and Lisbon Treaties and domestic implementing legislation, German citizens have raised constitutional complaints alleging violations of the

Constitutional Court. Verfassungsgerichtshof (VfGH) [Constitutional Court], Case SV 1/10-9 Treaty of Lisbon II, order of June 12, 2010.

${ }^{38}$ See concerns expressed by EU Commissioner for the Internal Market and Services in the speech at Europe House, London, July 12, 2013, called The Single Market in Financial Services: We Need the UK on Board, available at http://europa.eu/rapid/press-release_SPEECH-13-636_en.htm.

${ }^{39}$ Mendez \& Mendez, supra note 31, at 227-29.

40 Grundgesetz für die Bundesrepublik Deutschland [Grundgesetz] [GG] [Basic Law], art. 23.1 (Ger.).

${ }^{41}$ Bundesverfassungsgericht [BVerfG - Federal Constitutional Court], Case No. 2BvE 2/08, para. 243 (June 30, 2009), https://www.bundesverfassungsgericht.de/entscheidungen/es20090630_2bve000208en.html.

${ }^{42}$ Grundgesetz [GG] [Basic Law], arts. 23.1, 79.2, 79.3. 
principle of democracy and the right to vote. ${ }^{43}$ Such complaints, however, have not been formulated in terms of a right to a referendum prior to ratification, so the Federal Constitutional Court ("FCC") has not had to decide on its existence as a constitutional right. In Obiter, the FCC commented that the Basic Law may be changed to allow for referendum. ${ }^{44}$ Still, in the most recent case relating to the legality of establishing the European Stability Mechanism, where over 37,000 constitutional complaints were lodged, the FCC did not elaborate on this possibility or require a referendum. ${ }^{45}$ There is a strong line of reasoning throughout these cases which points to pre-legislative controls through the Bundestag exercising its constitutional responsibilities-ensuring representation of the popular will, future parliaments not bound by restricted competences, budgetary autonomy, the right to participate in decision-making, and the right to information. ${ }^{46}$

\section{Polish Parliamentary Consent}

Poland's Constitution requires prior parliamentary consent through statute for international agreements. The statute must pass with two-third votes in the Sejm and twothird votes in the Senate. ${ }^{47}$ Nationwide referendum is an alternative to parliamentary consent to treaty ratification, but this is by no means the norm because the Sejm ultimately decides on the method of consent. ${ }^{48} \mathrm{~A}$ general referendum provision provides that a nationwide referendum "may be held in respect of matters of particular importance to the State." ${ }^{\prime 9}$ There is, however, no clarification of what these "matters" might be and the power to order a referendum resides either with the Sejm or the President with the Senate's consent. ${ }^{50}$ Although referendum was first used for Poland's accession to the EU,

${ }^{43}$ See 89 BverfGE 155; see also Bundesverfassungsgericht [BVerfG - Federal Constitutional Court], Case No. 2BvE 2/08, (June 30, 2009).

\footnotetext{
${ }^{44}$ See Bundesverfassungsgericht [BVerfG - Federal Constitutional Court], Case No. 2BvE 2/08, para. 270 (June 30, 2009).

${ }^{45}$ See Bundesverfassungsgericht [BVerfG - Federal Constitutional Court], Case No. 2BvR 1390/12 (Sept. 12, 2012) [hereinafter ESM Treaty Temporary Injunctions]; See Bundesverfassungsgericht [BVerfG - Federal Constitutional Court], Case No. 2BvR 1390/12 (Mar. 18, 2014) [hereinafter ESM Treaty Decision].

${ }^{46}$ See 89 BverfGE 155, paras. 56-63, 94-96; see also Bundesverfassungsgericht [BVerfG - Federal Constitutional Court], Case No. 2BvE 2/08, paras. 210, 246-60, 375, 383 (June 30, 2009); see also ESM Treaty Temporary Injunctions at paras. 208-15, 286-87; see also ESM Treaty Decision at paras. 160-66.

${ }^{47}$ Tekst Konstytucji Rzeczypospolitej Polskiej z dnia 2 kwietnia 1997 r. [Constitution] arts. 90(1), (2) (Poland).

${ }^{48}$ See id. arts. 90(3), (4).

${ }^{49}$ See id. art. $125(1)$.

${ }^{50}$ See id. arts. 125(1), (2).
} 
the fact that it has not been used in subsequent EU matters-for example, changing the Constitution to enable extradition of Polish nationals under a European Council Decision or establishing the European Stability Mechanism-proves it is not intended as a pervasive constitutional mechanism. Decisions of the Polish Constitutional Tribunal ${ }^{51}$ indicate that parliamentary consent is the preferred pre-legislative control over EU matters while referendums are a last resort providing "social legitimi[z]ation of a decision that is of such great significance for the state."

\section{UK Parliamentary Approval and Referendum Triggers}

Until 2010, it was a matter of constitutional convention-the "Ponsonby rule" - for parliament to be consulted before ratification of a treaty. This rule is now enshrined in statute under section 20 of the Constitutional Reform and Governance Act 2010 ("the Reform Act"). ${ }^{53}$ Section 20 provides that a treaty cannot be ratified unless: (1) A government minister lays before parliament a copy of the treaty; (2) the treaty is published in a way that a government minister thinks appropriate; and (3) twenty-one parliamentary sitting days expires without either House-Commons or Lords-opposing ratification. ${ }^{54}$ If the House of Commons decides against ratification, the treaty may still be ratified subject to: (1) The government making a statement to parliament indicating it should be ratified and explaining why; and (2) twenty-one days further expires without the House of Commons deciding against ratification. Should the House of Lords be the only one opposing ratification, the government can still ratify if it makes a statement to parliament explaining its decision. In exceptional cases, where the government decides parliamentary consultation and approval are not required, the treaty may be ratified. ${ }^{55}$

Elected representatives in the House of Commons have an opportunity to scrutinize provisions of the treaty and raise concerns before ratification takes place. In fulfillment of their parliamentary duties, MPs would seek clarification and consult constituency

\footnotetext{
${ }^{51}$ See K18/04 Polish Membership of the European Union (Accession Treaty), Polish Constitutional Tribunal, Judgment of May 11, 2005; K32/09 Treaty of Lisbon, Judgment of Sept. 24, 2010; P1/05 Application of the European Arrest Warrant to Polish Citizens, Polish Constitutional Tribunal, Decision of Apr. 27, 2005; K33/12 The Act on the ratification of the European Council Decision of Mar. 25, 2011 amending Article 136 TFEU with regard to a stability mechanism for Member States whose currency is the euro, Judgment of June 26, 2013 [hereinafter ESM Decision].

52 See ESM Decision at 84 (dissenting Opinion of Judge Marek Zubik (English translation)).

53 Constitutional Reform and Governance Act 2010, c. 25, § 20 [hereinafter The Reform Act].

${ }^{54}$ See id. $\S 20(1)(a),(c)$.

${ }^{55}$ See id. §§ 20(4)-(5), 20(8), 22(1).
} 
members. But there are a number of mechanisms under the Reform Act-twenty-one days extension not leading to a vote against by the House of Commons; overruling a vote against from the House of Lords; exceptional cases category-which enable the government to push through ratification without parliamentary approval. Thus, the Crown's prerogative is not completely under statutory control.

Generally, future EU treaties and legislation are now subject to one or more requirements - for example, parliamentary approval, act of parliament, or referendumunder Part 1 of the European Union Act 2011 ("the EU Act"). ${ }^{56}$ The EU Act continues to recognize supremacy in relation to "directly applicable or directly effective EU law," and the obligation to interpret UK law in conformity with EU law. ${ }^{57}$ There is an attempt at reasserting parliamentary sovereignty by making the application of EU law contingent on the continuing existence of the Communities Act, the statute originally incorporating the EC treaties. Given the recent parliamentary vote supporting a membership referendum, parliamentary sovereignty seems re-positioned to enable future express repeal of the Communities Act. But the possibility of express repeal and parliament's limitation of its own sovereignty are already recognized in case law, so it is difficult to see what else this provision adds. ${ }^{58}$ Perhaps it is irrelevant that parliamentary sovereignty is not explicitly mentioned when we look at the overall effect of the EU Act.

\subsection{EU Areas Requiring Only Parliamentary Approval}

A relatively mild form of pre-legislative control on consent is parliamentary approval provided for under section 10 of the EU Act. A motion is put before each House of Parliament, which agrees to the motion without amendment. ${ }^{59} \mathrm{EU}$ areas subject to only parliamentary approval range from extension of free movement of services to third country nationals, ${ }^{60}$ to EU accession to the European Convention for the Protection of

\footnotetext{
56 European Union Act 2011, c. 12, § 14(2)(c) [hereinafter The EU Act].

57 See id. § 18.

58 See Michael Gordon \& Michael Dougan, The United Kingdom's European Union Act 2011: Who Won the Bloody War Anyway?, EUR. L. Rev. 3, 7-8 (2012) (arguing that $\S 18$ does not represent a "sovereignty clause" and fails to explain how UK law is reconciled with EU supremacy).

${ }^{59}$ See The EU Act $\S 9(3)$.

${ }^{60}$ See id. $\S 10(1)(a)$ (relating to Article 56 of the TFEU).
} 
Human Rights and Fundamental Freedoms. ${ }^{61}$ Other areas relate to changes to statutes of EU institutions and to the number of Advocates-General. ${ }^{62}$

3.2 EU Areas Requiring Only an Act of Parliament

A second form of pre-legislative control directly involves the legislature and a specific legislative act before the EU measure can take effect. The following Council of Ministers ("the Council") decisions require approval only by an act of parliament: Strengthening EU citizens' rights-free movement, residence and the right to vote; ${ }^{63}$ the election of members of the European Parliament ("MEPs") in accordance with a uniform procedure or common principles of member states; ${ }^{64}$ conferring jurisdiction on the CJEU in disputes relating to $\mathrm{EU}$ acts which give rise to European intellectual property rights; ${ }^{65}$ laying down the provisions relating to the system of own resources of the EU; ${ }^{66}$ altering the number of Commission members; ${ }^{67}$ exercising the passerelle clause in certain EU areas to change voting from unanimity to qualified majority voting, or from the special legislative procedure to the ordinary legislative procedure; ${ }^{68}$ adopting measures to take a step backwards in EU law regarding liberalization of movement of capital to or from third countries; ${ }^{69}$ replacing Protocol No. 12 on excessive deficit procedure; ${ }^{70}$ exercising the passerelle clause in relation to enhanced cooperation matters in which the UK participates

${ }^{61}$ See id. $\S 10(4)$ (relating to Article 6(2) of TEU). Accession must be agreed to unanimously under Article 218(8) TFEU, after approval by member states in accordance with their constitutional requirements.

${ }^{62}$ See id. $\S 10(1)(b)-(f)$ : Amendment to the Statute of the European System of Central Banks or of the European Central Bank (Article 129(3) of TFEU); an increase in the number of Advocates-General (Article 252 of TFEU); the establishment of specialized courts attached to the General Court (Article 257 of TFEU); amendment to the Statute of the Court of Justice of the European Union (Article 281 of TFEU); amendment to the Statute of the European Investment Bank (Article 308 of TFEU).

${ }^{63}$ See id. $\S 7(2)(a)$ (relating to Article 25 of TFEU).

${ }^{64}$ See id. $\S 7(2)($ b) (relating to Article 223(1) of TFEU).

${ }^{65}$ See id. $\S 7(2)(c)$ (relating to Article 262 TFEU).

${ }^{66}$ See id. $\S 7(2)(d)$ (relating to Article 311 TFEU).

${ }^{67}$ See id. $\S 7(4)(a)$ (relating to Article 17(5) TEU).

${ }^{68}$ See id. $\S 7(4)($ b) (relating to Article 48(7) TEU). The certain EU areas relate to all those provisions not listed in Schedule 1 of the EU Act (for example, family law with cross-border implications and the number of AdvocatesGenerals).

${ }^{69}$ See id. $\S 7(4)(c)$ (relating to Article 64(3) of TFEU).

70 See id. $\S 7(4)(d)$ (relating to Article 126(14) of TFEU). 
and which do not also require a referendum; ${ }^{71}$ and exercising the general competence provision, also known as the flexibility clause. ${ }^{72}$

With the exception of exercising the passerelle and general competence clauses, which also require a referendum, the above areas generally reflect the treaties' respect for national identity and recognition of each member state's constitutional requirements. Interestingly, the EU Act does not require a referendum for any Council decision to strengthen EU citizens' rights, which is at odds with giving people more say in EU matters of direct relevance. Similarly, decisions on MEP elections are a matter of direct interest to UK citizens with the potential to increase awareness and engagement in EU matters. In contrast, technical areas relating to EU voting procedures and exercise of the general competence provision are also subject to a referendum. This creates an imbalance between attracting electorate interest on substantive matters and losing their interest through disengagement in matters perceived as technical.

\subsection{EU Areas Requiring an Act of Parliament and a Referendum}

"Referendum" is mentioned thirty-four times in the EU Act, more so than "act of parliament" or "parliamentary approval." ${ }^{73}$ From this basic count, it appears parliament favors direct democracy as a method of domestic control over EU decision-making. The referendum condition requires that a referendum takes place, with a majority vote in favor, before an act of parliament approving an EU treaty or Council decision comes into force. ${ }^{74}$ Under section 13 of the EU Act, a non-partisan regulatory body, the Electoral Commission, oversees the referendum process. This Commission "must take whatever steps they think appropriate to promote public awareness of the referendum and how to vote in it" and "may take whatever steps they think appropriate to promote public awareness of the subject-matter of the referendum." ${ }^{75}$ This is a broad remit enabling setting standards for political campaigning and ensuring proper and accurate

\footnotetext{
${ }^{71}$ See id. $\S \S 7(4)(e)-(f)$ (relating to Articles 333(1) and 333(2) of TFEU).

${ }^{72}$ See id. § 8(3) (relating to Article 352 of TFEU). But note two other methods for approval of general competence decisions: Motion before Parliament and each House agrees without amendment $(\S 8(4))$; or a statement to Parliament that the decision is exempt from approval (§ 8(5)).

73 "Act of parliament" is referred to eleven times, and "parliamentary approval" seven times.

${ }^{74}$ See The EU Act $\S \S 2(2), 3(2)$.

${ }^{75}$ Emphasis added. Section 13(1)(c) of the Political Parties, Elections and Referendum Act 2000, c. 41, (The PPERA) already requires the Electoral Commission to promote public awareness of the institutions of the EU.
} 
dissemination of referendum issues. ${ }^{76}$ To improve public understanding and engagement with EU affairs, there is a need for stronger monitoring and enforcement by the Electoral Commission-investigating and sanctioning referendum campaigns which misrepresent issues or mislead the public hindering access to relevant information and informed choice in voting.

The following areas require both an act of parliament and a referendum: Treaty revisions relating to the TEU or Treaty on the Functioning of the European Union ("TFEU"); ${ }^{78}$ amendment of the TFEU under the simplified revision procedure; ${ }^{79}$ extension of an existing EU competence-exclusive, shared, or supporting-or conferral of a new one; ${ }^{80}$ and changes to a voting procedure-especially from unanimity to qualified majority voting, or from special legislative procedure to ordinary legislative procedure-relating to specific areas. $^{81}$ There are also wide policy areas subject to referendum as these are of national

${ }^{76}$ Under the PPERA the Electoral Commission has wide ranging powers: Section $6 \mathrm{~B}$ observations of working practices by representatives of the Commission; Section 6C and 6D accredited election observers; Section 8 powers regarding elections exercisable on recommendation of the Commission; Section 11 broadcasters to have regard to Commission's views on party political broadcasts.

77 Sections 125-27 of the PPERA set general restrictions on publication of promotional material and campaign broadcasts but not in relation to the accuracy of information.

78 See The EU Act $\S 2(1)$ (relating to Article 48(2)-(5) of TEU).

${ }^{79}$ See id. $\S 3(1)$ (relating to Article $48(6)$ of TEU).

${ }^{80}$ See id. $\S 4(1)(a)-(j)$ (relating to Articles 3,4 and 6 of TFEU).

${ }^{81}$ See id. $\S 4(1)(k)-(m)$ (relating to TEU provisions: Article 7(2) (serious and persistent breach determination by European Council); Article 14(2) (European Parliament composition); Article 15(4) (European Council consensus decisions); Article 17(5) (Commissioners); Article 19(2) (Judges and Advocates-General of the Court); Article 22(1) (EU strategic interests and objectives); Chapter 2 of Title V (CFS policy); Article 48(3), (4), (6) and (7) (treaty revision procedures); Article 49 (EU membership application); Article 50(3) (European Council decision extending treaties' application for withdrawing state)). TFEU provisions: Article 19(1) (measures against sexual, racial or ethnic, religious, age or sexual orientation discrimination); Article 21(3) (social security or social protection measures); Article 22(1) (non-national EU citizens standing and voting in state of residence local elections); Article 22(2) (same persons standing and voting in European Parliament elections in state of residence); Article 25 (strengthening EU citizens' rights); Article 77(3) (passports, identity cards, residence permits etc.); Article 82(2)(d) (minimum rules on criminal procedure); Article 83(1) (decision on other areas of crime); Article 86(1) and (4) (European Public Prosecutor's Office); Article 87(3) (police cooperation); Article 89 (cross-border operation by competent authorities); Article 113 (harmonization of indirect taxes); Article 115 (approximation of national laws affecting internal market); Article 121(2) (broad guidelines of economic policies); Article 126(14) (replacing protocol on excessive deficit procedure); Article 127(6) (conferral on European Central Bank prudential supervision tasks); Article 153(2)(b) (working conditions, social security etc.); Article 155(2) (agreements at EU level between management and labor); Article 192(2) (adoption of certain environmental measures); Article 194(3) (energy measures of a fiscal nature); Article 203 (association of countries and territories with the EU); Article 218(8) (certain international agreements); Art. 222(3) (implementation of solidarity clause having defense implications); Article 223(1) (uniform procedures for elections to European Parliament); Article 311 (own 
concern and the UK wants to maintain control-such policy areas include social policy, common defense, participation in the European Public Prosecutor's Office, environment, EU finance, enhanced cooperation, and border control. ${ }^{82}$

\section{Problems with Over-Reliance on Referendum}

The UK's referendum requirement covers broad EU areas relating to the full range of EU institutions' competences. There is concern for future treaty provision changes to alter the balance of power between EU and member state competences, as well as the possibility of majority rule in decision-making. In particular, any changes allowing Council decisions to be made by qualified majority voting instead of unanimity are subject to an act of parliament and referendum. This, however, is overly cautious and unnecessary to preserve the balance of power.

For example, under Article 7(2) TEU, the European Council may unanimously determine a serious and persistent breach by a member state of respect for human dignity, freedom, democracy, rule of law, and human rights. ${ }^{83}$ The Council can then act by qualified majority voting under Article 7(3) TEU to suspend certain membership rights for the offending state. ${ }^{84}$ The passerelle clause under Article 48(7) TEU cannot be invoked to change voting procedures under Articles 7(2) and 7(3) as this is excluded under Article 353 TFEU. ${ }^{85}$ Plus, there is no need to bypass the offending state's negative vote because they are barred from voting under Article 354 TFEU. ${ }^{86} \mathrm{~A}$ number of safeguards prevent abuse of serious breach determinations: Involvement of political and legislative institutions such as the European Council, the Council, and the European Parliament; setting voting procedures for each institution; voting procedures which cannot be changed; and the obvious political and diplomatic fallout for EU integration. Despite this, section 6(5)(b) Schedule 1 Part 1 of the EU Act makes such voting procedure change dependent on an act of parliament and a

\footnotetext{
resources decisions); Article 312(2) (multi-annual financial framework); Article 332 (expenditure on enhanced cooperation to be borne by member states other than those participating); Article 333(1) and (2) (enhanced cooperation); Article 346(2) (changes to list of military products exempt from internal market provisions); Article 352(1) (measures to attain EU objectives where treaties do not provide necessary powers).

${ }^{82}$ See generally The EU Act § 6(5).

${ }^{83}$ See TEU art. 7(2).

${ }^{84}$ See id. art. 7(3).

${ }^{85}$ See TFEU art. 353.

${ }^{86}$ See id. art. 354.
} 
referendum. ${ }^{87}$ Another example of overly cautious domestic controls is the requirement for both prior parliamentary approval and referendum to change voting procedures under Article 48(7) TEU and the exercise of EU competence under Article 352 TFEU.

Extensive use of referendums represents an absolutist notion of democratic legitimation through direct public voting. Referendums on EU voting procedures are clumsy brakes on internal operational rules that hinder efficient decision-making. Even in Germany, with a developed understanding of democratic participation through a constitutionally protected right to vote and state organs' legitimacy derived from that right, the absolutist notion is rejected.

In the ESM Treaty Decision, the German FCC deemed inadmissible constitutional complaints of breach of the right to vote if budgetary decisions are made by the Bundestag committee as opposed to the Bundestag plenary session, or if internal decisions of state organs are not subject to majority vote. Such internal procedures do not per se breach the principle of democracy or the right to vote. The right to vote is protected:

only to the extent that it is in danger of being rendered ineffective in an area that is essential for the political self-determination of the people-for example, if the democratic self-government of the people is permanently restricted in such a way that vital political decisions can no longer be made independently. ${ }^{88}$

By analogy, EU internal voting procedures are agreed on by representatives of member states to enable effective decision-making at the Council level. Subjecting these procedures to national referendums is to present citizens with a hollow sense of empowerment; that by casting a vote they somehow hold the EU accountable. It is far more important to hold governments and EU institutions accountable by having access to information on government voting positions and the basis for these, as well as a right to vote on substantive matters.

The UK's referendum condition goes beyond what some of the more active legislatures in member states are required to do. ${ }^{89}$ It may allay public concern at increased powers of EU

\footnotetext{
${ }^{87}$ See The EU Act $\S 6(5)(b)$, sch. 1.

${ }^{88}$ See ESM Treaty Temporary Injunctions, Case No. 2BvR 1390/12 (Sept. 12, 2012); see also ESM Treaty Decision, Case No. 2BvR 1390/12 (Mar. 18, 2014), at paras. 124-28.

${ }^{89}$ In Germany only prior legislative approval is necessary for participation in decisions under Article 48(7) TEU and Article 352 TFEU; see Bundesverfassungsgericht [BVerfG - Federal Constitutional Court], Case No. 2BvE 2/08, para. 409

(June

30 ,

2009),
} 
institutions and politicians' fickleness in reneging on referendum promises for significant transfer of sovereignty. ${ }^{90}$ But, by setting a wide referendum trigger, it achieves the opposite effect of democratic accountability. Voting on technical areas inconsequential to UK constitutional law may lead to voter apathy, low turnouts, and further distancing from EU matters. ${ }^{91}$ Formulation of the referendum question and the information available will be crucial to ensuring public understanding. ${ }^{92}$

\section{Constitutional Principles}

National consent on its own does not provide an adequate basis for accountability of supranational decisions. For this, we must look to EU constitutional principles. While there is no formal document referred to as the "EU Constitution," the founding treaties are now consolidated into the TEU and the TFEU ("Treaties"). These Treaties contain principles forming the basis for the EU's continuation, representing constitutional principles. ${ }^{93}$ As a properly functioning and justifiable legal order, the EU must remain accessible, applicable and effective. ${ }^{94}$ Accessibility means the law should be practicable and available to the public in a form that is clear. This can range from seeking national approval and correct transposition into domestic law to accurate translation of EU legislation into the

https://www.bundesverfassungsgericht.de/entscheidungen/es20090630_2bve000208en.html. Contrast with the Czech Republic, which does not require prior parliamentary approval for use of Article 352 TFEU or Article 48(7) TEU; Ústavní soud České republiky dne 26.11.2008 (ÚS) [Constitutional Court] [Decision of the Constitutional Court of Nov. 26, 2008], sp.zn PI. ÚS 19/08, paras. 150, 165 (Czech).

${ }^{90}$ The UK government reneged on an election promise to hold a referendum on the proposed 2004 Constitution Treaty. This was unsuccessfully challenged in R (Wheeler) v. Office of the Prime Minister [2008] EWHC 1409 (Admin). On 16 July 2008, the UK ratified the watered down version of a constitution under the Lisbon Treaty without holding a referendum.

91 UK turnout at the June 2009 European Parliamentary elections was thirty-four-point-five percent compared to forty-three percent across the EU as a whole. Historically, UK turnouts tend to be lower than the EU average as well as being lower than other types of election in the UK. See The European Parliamentary and Local Government Elections June 2009: Report on the Administration of the 4 June 2009 Elections (The Electoral Commission: October 2009), 24-26, http://www.electoralcommission.org.uk/_data/assets/pdf_file/0006/81483/047-elections-reportfinal-web.pdf.

92 For example, see concerns about rules governing referendum campaigns in Ireland, Mendez \& Mendez, supra note 31 , at 227.

93 See Principles of European Constitutional LaW (Armin Von Bogdandy \& J. Bast eds., 2009); Craig, supra note 6.

94 See S. and Marper v. United Kingdom, App. No. 30562/04 and 30566/04 (Apr. 12, 2008), http://hudoc.echr.coe.int/; see also Joined Cases C-465/00, C-138/01, and C-139/01, Rechnungshof v. Österreichischer Rundfunk and Others and Christa Neukomm and Joseph Lauermann v. Österreichischer Rundfunk, 2003 E.C.R. I-5014. 
appropriate language of the member state. ${ }^{95}$ Applicability means the law must be relevant and valid to a given situation in a member state without necessarily requiring domestic implementation. ${ }^{96}$ Effectiveness involves making the law justiciable so that EU citizens have domestic remedies for breaches of law or violations of rights. ${ }^{97}$ Accessibility, applicability and effectiveness can be seen through constitutional principles of citizenship, political rights and democracy. ${ }^{98}$

\section{The Concept of Citizenship and Rights}

The 1992 Treaty of Maastricht (i.e. the TEU) introduced the concept of EU citizenship for the first time. ${ }^{99}$ The EU took on a distinctly political and cultural character by defining a geographical area consisting not only simply of member states but also of citizens. The Treaties subsequently developed the meaning of citizenship from the "four freedoms"namely, the movement of persons, goods, capital, and services-espoused in the original treaties. ${ }^{100}$ Under Article 20(1) TFEU, citizenship means every person who is a national of a member state is also a citizen of the EU. ${ }^{101}$ While nationality is a matter for each member state to determine, once recognized, the individual automatically has EU citizenship. ${ }^{102}$ Every EU citizen has the following rights: to move and reside in another member state; to vote and stand as a candidate in municipal and European Parliamentary elections; to diplomatic and consular protection in a third state where their state of nationality has no

\footnotetext{
95 See TEU art. 12; see also TFEU art. 197(1)-(2); see also TEU protocol no. 1; Regulation 1049/2001 (public access to EU institutions' documents): Recital 15, Arts. 2(1), 14(2); Art. 29 of the Rules of Procedure of the Court.

96 See TFEU arts. 18, 21, 28, 30, 34, 35, 49, 56, 110.

97 See direct effect in Case 26/62, Van Gend en Loos v. Nederlandse Administratie der Belastingen, 1963 E.C.R.; incidental direct effect in C-194/94, CIA Security International, 1996 E.C.R. I-2201; indirect effect in Case 14/83 Von Colson and Kamann, 1984 E.C.R. 1891; and state liability in Case C-6 \& 9/90, Francovich v. Italy, 1991 E.C.R. I5357.

98 See Michael Dougan, The Constitutional Dimension to the Case of Union Citizenship, 31 EUR. L. REV. 613 (2006); see also Neil MacCormick, Democracy, Subsidiarity and Citizenship in the European Commonwealth, 16 L. \& PHIL. 331 (1997). For a contrasting view that citizenship has had "integrative" rather than "constitutive" effects see Jo Shaw, Citizenship: Contrasting Dynamics at the Interface of Integration and Constitutionalism, in THE EVOLUTION OF EU LAW 608-09 (Paul Craig \& Grainne De Burca eds., 2011).

99 See TEU art. 9; see id. Preamble; see also TFEU art. 20(1)

100 See id. art. 45(1) (freedom of movement for workers); see also Title II TFEU (free movement of goods); see also TFEU art. 63(1) (movement of capital); see also TFEU art. 56 (freedom to provide services).

${ }^{101}$ See TFEU art. 20(1).

102 See Case C-369/90, 1992 E.C.R. I-4239; see also Case C-135/08, Rottman v. Bayern, 2010 E.C.R. I-1449.
} 
representation; and to petition the European Parliament, apply to the European Ombudsman, and address EU institutions and advisory bodies. ${ }^{103}$ These rights are replicated under Articles 39 to 46 on the Charter of Fundamental Rights of the European Union ("the Charter"). ${ }^{104}$

Citizenship and rights are part of the foundation for creating an ever closer union among the peoples of Europe. Articles 1, 3(2), and 3(5) TEU refer to the "citizen." ${ }^{105}$ Article 1 identifies the TEU as marking "a new stage in the process of creating an ever closer union among the peoples of Europe, in which decisions are taken as openly as possible and as closely as possible to the citizen." ${ }^{106}$ Under Article 3(2), EU citizens have "an area of freedom, security, and justice without internal frontiers, in which free movement of persons is ensured." ${ }^{107}$ Article 3(5) obliges the EU to protect its citizens in relations with non-member states. ${ }^{108}$ From these three provisions, it is clear that the status of citizen confers certain discernible rights: transparency and accountability of decision-making; access to an area where there is free movement; and diplomatic and consular protection. These rights are all predicated on the individual and there is a sense of individualism in the values and principles espoused under the Treaties. ${ }^{109}$ The principle of democracy, as envisaged under the Treaties, is the basis for understanding EU citizens' individual political rights.

\section{The Principle of Democracy and Political Rights}

Democracy is a founding value and principle enumerated throughout the Treaties. ${ }^{110}$ The EU is founded on representative democracy and Title II of the TEU devotes a section to "Provisions on Democratic Principles." ${ }^{111}$ Looking at these provisions, it becomes clear that

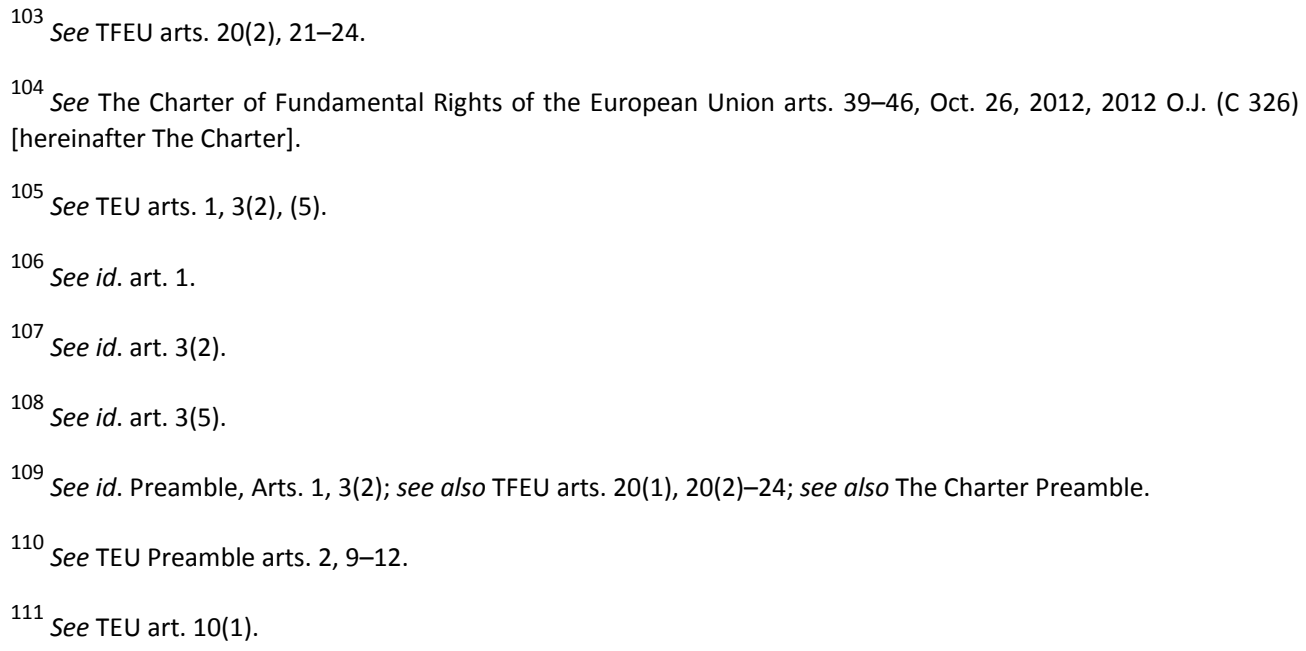


"peoples" and "individuals" are complementary categories: Peoples of the Union are the peoples of each member state and individuals are EU citizens. ${ }^{112}$ This has been referred to as a "dual structure of democratic legitimation" whereby the EU is accountable to both individuals and peoples. ${ }^{113}$ Under Article 10(2) TEU, citizens are directly represented in the European Parliament. ${ }^{114}$ MEPs are representatives of EU citizens and are elected once every five years by direct universal suffrage in a free and secret ballot. ${ }^{115}$ Also under Article 10(2) TEU, peoples of member states are represented in the European Council by their heads of state or government and in the Council by their governments, which are themselves democratically accountable either to their national parliaments or citizens. ${ }^{116}$ The role of national parliaments is also seen as a fundamental principle of democracy under Article 12 TEU. $^{117}$

So EU decision-making and functioning is on the basis of representative democracy with direct and indirect links to individual citizens in member states. These links can be seen through the exercise of political rights and operations of EU institutions.

\section{Right of Participation}

Apart from democratic participation, which takes place at the national level, there is an additional layer of participation operational at the EU level. Every EU citizen has the right to participate in the democratic life of the EU. ${ }^{118}$ Participation is on the basis of equality and transparency. In all its activities, the EU is obliged to observe the principle of equality of its citizens, and EU institutions must treat citizens equally. ${ }^{119}$ This principle is not restricted to individuals. Representative associations must also be given the opportunity to make known and publicly exchange their views in all areas of EU action. ${ }^{120}$ Popular vote

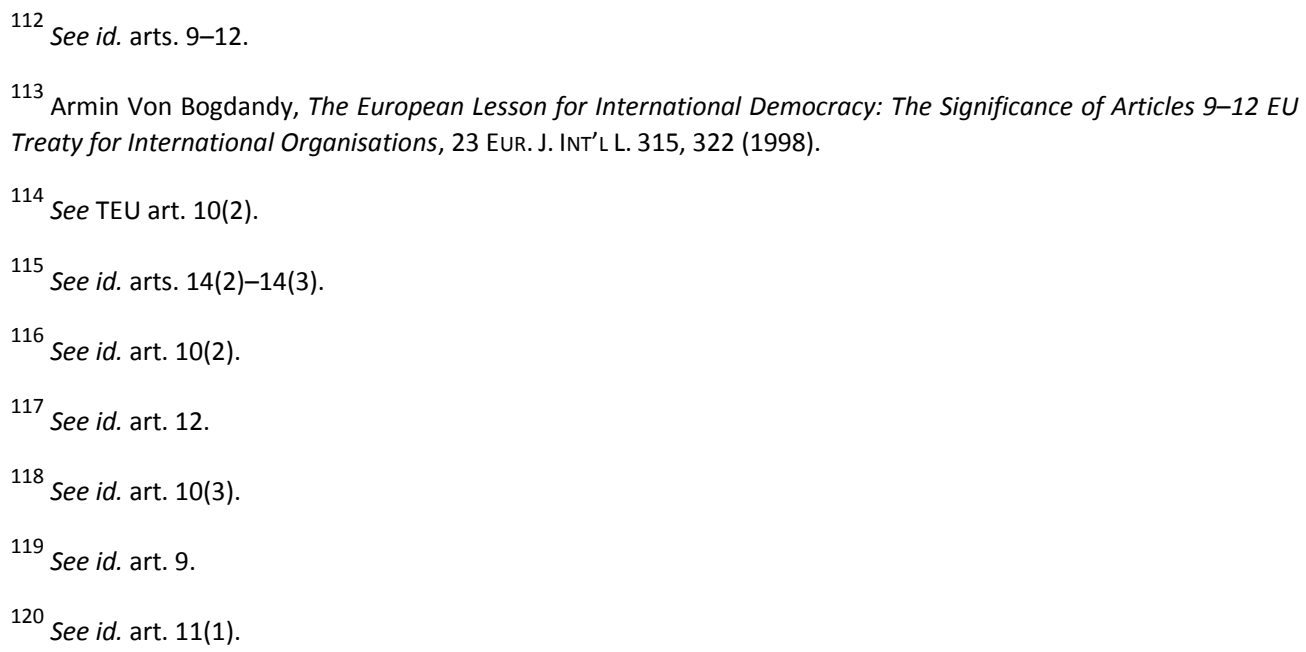


decision-making is also considered part of democratic participation; for example, if there are at least one million EU citizens who are nationals of a significant number of member states, they can propose new legislation to the European Commission ("the Commission"). ${ }^{121}$ This is similar to UK e-petitions requiring 100,000 signatures for an issue to be considered for debate in the House of Commons. ${ }^{122}$ Since 1 April 2012, Regulation No. 211/2011 applies setting rules and procedures for popular vote decision-making. ${ }^{123} \mathrm{~A}$ working group of experts was established in 2011 to exchange views, know-how, and best practice on the tasks to be carried out by the member states. ${ }^{124}$

To date, the Commission has received twenty-seven requests to register proposed initiatives on unconditional basic income, high-quality education for all, media pluralism, and voting rights. ${ }^{125}$ Right2Water, under the slogan "water is a public good, not a commodity," was the first citizen-based initiative to achieve one million signatures for legislation to implement and to promote the right to water and sanitation as an essential public services for all. ${ }^{126}$ Although this citizen-based initiative attracted enough support across member states to place it on the Commission's agenda, it ultimately failed to convince the Commission of the need for legislative reform. Campaigners were misguided in their understanding of existing EU legislation in calling for water services to be exempt from internal market liberalization rules when water services were already exempt as "services of general economic interest." ${ }^{127}$ A recent pro-life and anti-abortion citizens' initiative, "One of Us," called for the EU to "ban and end the financing of activities which presuppose the destruction of human embryos, in particular in the areas of research,

${ }^{121}$ See id. art. 11(4).

${ }^{122}$ This is a government initiative and is not provided for under statute. Ten thousand signatures get a response from the government. One hundred thousand signatures mean the petition will be considered for debate in Parliament. See Petition Parliament and the Government, GOV.UK (July 20, 2015), https://www.gov.uk/petition-government.

${ }^{123}$ Commission Regulation No. 211/2011, 2011 O.J. (L 65), recitals 5-6, arts. 3(4), 7(2) (voting requirements); 3(2), 4, 5, 8, 9 (organizers' duties); 8 (certification duties of member states); 10-11 (Commission's duties).

${ }^{124}$ See the expert group's report of Dec. 2, 2014, MEETING OF THE EXPERT GROUP ON THE CITIZENS' INITIATIVE, available at http://ec.europa.eu/citizens-initiative/public/legislative-framework.

${ }^{125}$ See European Commission, Under Article 25 TFEU: On Progress Towards Effective EU Citizenship 2011-2013, at 7-8, COM (2013) 270 final (May 8, 2013) [hereinafter 2013 Article 25 Report].

126 European Citizens' Initiative Hits 1 Million Signatures, EUROPEAN COMmISSION (Feb. 11, 2013), www.europa.eu/rapid/press-release_IP-13-107_en.htm; see also Water and Sanitation are a Human Right!, www.right2water.eu/ (last visited Aug. 2, 2015).

${ }^{127}$ Directive 2006/123/EC of the European Parliament and the Council of 12 December 2006 on Services in the Internal Market, 2006 O.J. (L 376), art. 17(1)(d). 
development aid and public health." ${ }^{128}$ The Commission rejected this one as well. ${ }^{129}$ These initiatives illustrate both the limitations of popular vote decision-making where there is lack of understanding of EU law and the potential for initiatives to be hijacked by narrow political interests.

The right to participate includes being able to inform, debate, and vote on European issues. Awareness and understanding of European issues is stimulated through open and transparent discussion, access to information and active engagement. Recent CJEU decisions have upheld the right of citizens and national parliamentarians to access information regarding member states' negotiating positions and proposals for legislative amendments. ${ }^{130}$ It is also the responsibility of EU institutions and stakeholders to create political awareness and inform the public. ${ }^{131}$ According to Article 10(4) TEU, political parties at the European level contribute to forming political awareness and to expressing the will of citizens of the Union. How do political parties create awareness? MEPs should be properly informed on EU affairs and debates of the European Parliament. They must then properly and accurately convey and disseminate such information to EU citizens. Evidence suggests otherwise: Sixty-eight percent of EU citizens do not feel sufficiently informed, and seventy-four percent of people with a negative view of the EU admit that they are not well informed. ${ }^{132} \mathrm{TV}$ is the most popular medium for dissemination of information, but "national TV channels often report on European topics from a national point of view for a national audience." ${ }^{133}$ The Commission recognizes that "providing citizens with information about European issues from a European point of view, but also

${ }^{128}$ Communication from the Commission on the European Citizens' Initiative "One of Us," at 15, COM (2014) 355 final (May 28, 2014).

${ }^{129}$ Id. at 17-19. The Commission concluded legislative amendments were not necessary because: (1) The 2012 Financial Regulation complies with EU primary legislation protecting human dignity, the right to life, and the right to the integrity of the person; (2) the 2013 Horizon 2020 Regulation provisions on human embryonic stem cell research comply with the EU Treaties and the Charter of Fundamental Rights of the European Union; and (3) the existing legal framework for development cooperation enables managing development funding in a way that helps minimize abortions in developing countries, and a funding ban would undermine other objectives, such as maternal health. See id.

${ }^{130}$ C-280/11P, Council v. Access Info Europe (Oct. 17, 2013), http://curia.europa.eu; Case C-350/12P, Council v. in 't Veld (July 3, 2013), http: //curia.europa.eu.

${ }^{131}$ See TEU art. 10(4).

${ }^{132}$ See European Commission, EU Citizenship Report 2013, at 24, COM (2013) 269 final (May 8, 2013) [hereinafter EU Citizenship Report 2013].

133 Id. 
from a range of national perspectives from other member states, could increase the European public space and contribute to a more informed democratic debate."134

\section{Transparency and Accountability of Decision-Making}

Transparency of decision-making is upheld by EU decisions being taken as openly and as closely as possible to the citizens. ${ }^{135} \mathrm{EU}$ institutions are obliged to maintain an open, transparent, and regular dialogue with representative associations and civil society. ${ }^{136}$ The Commission has a particular responsibility to ensure EU actions are coherent and transparent by carrying out broad consultations with parties concerned. ${ }^{137}$ There are a number of specific treaty provisions that give effect to transparency. Article 16(8) TEU requires the Council to meet in public when it deliberates and votes on a draft legislative act. $^{138}$ There is a general obligation for EU institutions to provide reasons for their decisions; ${ }^{139}$ this is supported by the right to good administration under Article 41 of the Charter. ${ }^{140} \mathrm{EU}$ decisions are subject to judicial review under Article 263 TFEU, and in a number of cases the CJEU has found an EU institution to lack competence, infringe a treaty rule, or misuse its powers. ${ }^{141}$

Under Article 296 TFEU, decisions on new legislation must be based on stated reasons. ${ }^{142}$ With the prerogative to initiate new legislation, the Commission is obliged to explain and justify the need and relevance of proposed legislative acts. ${ }^{143}$ If the flexibility clause under

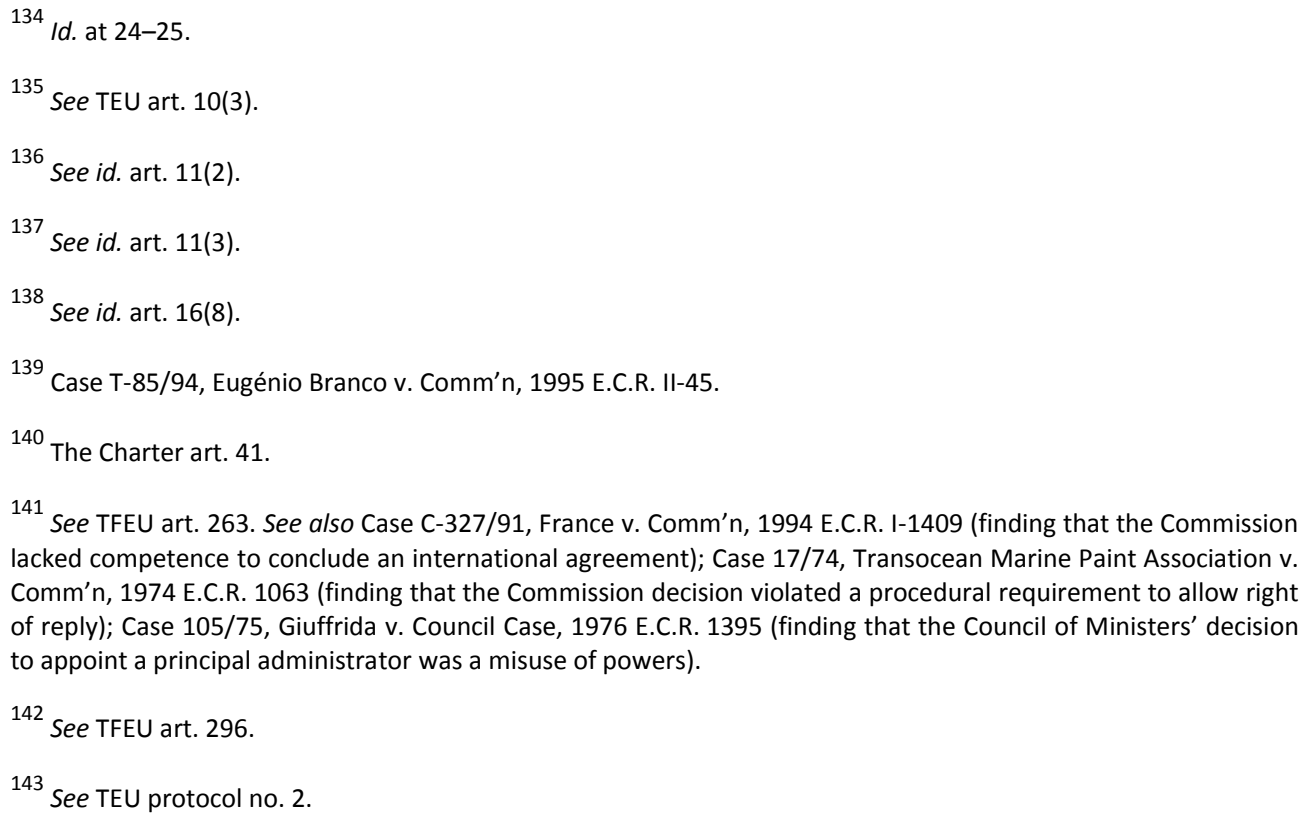


Article 352 TFEU is invoked to introduce new legislation, it must inform national parliaments of such proposals to enable subsidiarity monitoring under Article 5(3) TEU and Protocol (No. 2) on the Application of the Principles of Subsidiarity and Proportionality ("Protocol No. 2"). ${ }^{144}$

The Commission has an obligation to provide reasoned opinions prior to enforcement action against member states for breach of treaty obligations. In the reasoned opinion of June 2013, Belgium, Cyprus, Czech Republic, Portugal, and Romania were directed to comply with Directive 2009/119/EC to maintain minimum stockpiles of crude oil. ${ }^{145}$ In these instances, an administrative stage allows for the alleged offending state to negotiate and exchange opinions with the Commission prior to the commencement of legal proceedings. ${ }^{146}$ If the state fails to comply, the Commission must satisfy procedural justice by producing a reasoned opinion setting out the grounds of complaint to enable the state to prepare a defense and rectify the breach within a timeframe. ${ }^{147}$ On occasion, the Commission has been in breach of procedural justice by commencing proceedings after the member state complied with the reasoned opinion. ${ }^{148}$

The right of EU citizens to complain to the European Ombudsman ("the Ombudsman") about maladministration in the activities of EU institutions, bodies, offices, and agencies is a means of raising transparency and accountability issues. ${ }^{149}$ The most common focus of the Ombudsman's inquiries is lack of transparency in EU administration. In 2012, twentyone and a half percent of cases were transparency-related, as compared with thirty-three percent in 2010 and twenty-five percent in $2011 .{ }^{150}$ In relation to the right to petition the

${ }^{144}$ See TFEU art. 352(2); TEU protocol no. 2.

145 See June 2013: Belgium, Cyprus, Czech Republic, Portugal, and Romania Are Called Upon to Comply with EU Rules on Oil Stocks, EUROPEAN COMmISSION, available at https: / /ec.europa.eu/energy/en/june-2013-belgiumcyprus-czech-republic-portugal-and-romania-are-called-upon-comply-eu-rules-oil (last visited Aug. 3, 2015); see also June Infringements Package: Main Decisions, European Commission 7 (June 20, 2013), http://ec.europa.eu/energy/sites/ener/files/documents/MEMO-13-583_EN.pdf.

${ }^{146}$ See TFEU art. 258. The Commission will attempt to resolve matters informally. If the matters remain unresolved, the Commission will issue a letter of formal notice requesting a response from the member state.

${ }^{147}$ See Case C-1/00, Comm'n v. France, 2001 E.C.R. I-9989, para. 54; Case C-230/99, Comm'n v. France, 2001 E.C.R. I-1169, para. 31.

${ }^{148}$ Case C-439/99, Comm'n v. Italy, 2002 E.C.R. I-305, para. 17; Case C-362/90, Comm'n v. Italy, 1992 E.C.R. I02353, para. 9 .

149

See TFEU art. 228; 2013 Article 25 Report, supra note 125, at 7.

${ }^{150}$ See 2013 Article 25 Report, supra note 125, at 7. 
European Parliament, one of the most common subject matters for petitions is fundamental rights and justice. ${ }^{151}$

\section{EU as Protector of Rights}

EU institutions have a monitoring and legislative role in relation to rights, enabling consistency and uniformity in application and implementation. Because these rights derive from the Treaties, it also makes sense to have supranational oversight. Thus, decisionmaking authority derives from upholding and protecting rights, representing Majone's "autonomous legitimacy" argument. ${ }^{152}$ There are various examples of the protector role under the Treaties.

\section{Oversight Responsibilities of the Commission}

As an impartial supranational body, to the extent that it is not composed of member state representatives, the Commission can be seen in its key role of standard-setting across the EU. It is entrusted with several oversight responsibilities. First, it promotes the general interest of the EU, takes appropriate initiatives to that end, and ensures application of the Treaties and measures adopted by EU institutions. This includes overseeing the application of EU law under the control of the CJEU. ${ }^{153}$ Second, it oversees the application of citizenship and rights throughout the EU. Every three years, it must compile a report on the application of citizenship and rights for the European Parliament and Council. On the basis of this report, the Council may adopt provisions to strengthen or add to rights in Article 20(2) TFEU. ${ }^{154}$ Third, it steers EU-wide standard-setting by making legislative proposals that may become legislative acts adopted by the European Parliament and Council. ${ }^{155}$

The Commission's 2013 Report points to areas of concern for application of citizenship rights. In relation to electoral rights, the Commission has pursued dialogues with member states regarding transposition of Directive 94/80/EC, the right of EU citizens to participate in municipal elections, and Directive 93/109/EC, the right of EU citizens to participate in European elections. ${ }^{156}$ As a result, the member states concerned amended their legislation

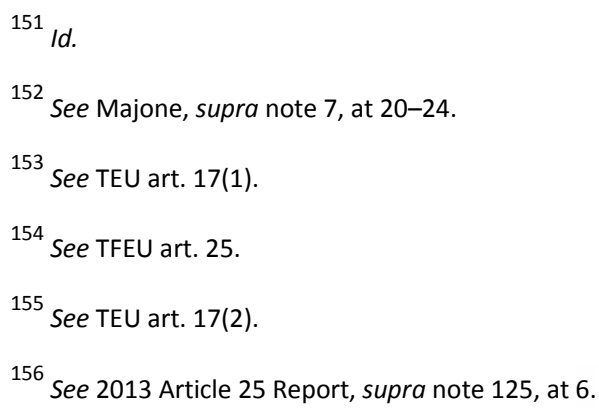


or announced amendments to comply with EU law. ${ }^{157}$ Eleven member states were contacted about not allowing non-national EU citizens to found or become members of political parties, contrary to Article 22 TFEU. ${ }^{158}$ While four member states clarified the situation, adopted national legislation in line with EU law, or announced amendments, the Commission took action against the seven remaining member states. ${ }^{159}$ The Commission recommends member states adopt targeted measures to stimulate citizens' participation in municipal elections and increase turnout. ${ }^{160}$ In preparation for the 2014 European elections, the Commission produced a communication and recommendation aimed at strengthening the European dimension to European elections, increasing efficiency and reducing the administrative burden. ${ }^{161}$

In relation to consular protection rights, the Commission has launched a dedicated website. ${ }^{162}$ In 2011, it also adopted a proposal for a Directive on consular protection for Union citizens abroad. This aims to establish clear and legally binding rules on cooperation and coordination between member states' consular authorities to ensure unrepresented EU citizens have non-discriminatory access to consular protection from other member states' diplomatic or consular representations in a third country.

\section{Legislative Functions of the European Parliament and the Council}

In the exercise of their legislative functions, the European Parliament and Council ("the legislature") can be seen as protectors of citizens' rights. As mentioned above, the Council may adopt provisions to strengthen or add to citizens' rights. ${ }^{163}$ The legislature also promotes and protects the development and exercise of rights in a number of ways. It may

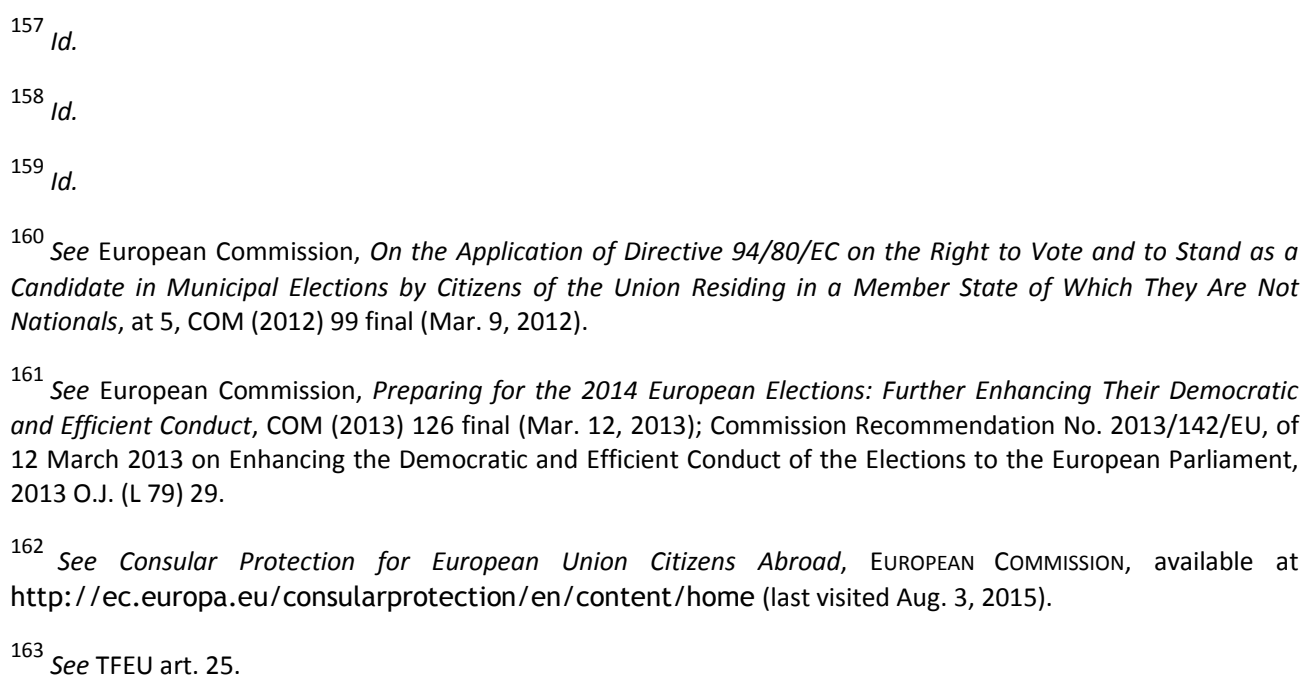
and Efficient Conduct, COM (2013) 126 final (Mar. 12, 2013); Commission Recommendation No. 2013/142/EU, of 12 March 2013 on Enhancing the Democratic and Efficient Conduct of the Elections to the European Parliament, 2013 O.J. (L 79) 29.

162 See Consular Protection for European Union Citizens Abroad, EUROPEAN COMMISSION, available at http: / /ec.europa.eu/consularprotection/en/content/home (last visited Aug. 3, 2015).

163 See TFEU art. 25. 
adopt rules designed to prohibit discrimination on the grounds of nationality. ${ }^{164}$ It may take appropriate action to combat discrimination on other grounds-sex, race, ethnicity, religion, disability, age, or sexual orientation. ${ }^{165}$ Although free movement of persons is an area of shared competence under Article 4(2)(a) TFEU, if action should prove necessary, the legislature may adopt provisions to facilitate the exercise of the right to move and reside. ${ }^{166} \mathrm{It}$ is obliged to issue directives or make regulations setting out measures required to bring about freedom of movement of workers. ${ }^{167}$ The exercise of the right to vote is subject to detailed arrangements by the Council, which may provide derogations for specific member states. ${ }^{168}$ On 20 December 2012, the Council adopted Directive 2013/1/EU, making it easier for EU citizens to stand as candidates in the 2014 European elections by only requiring production of an identity document and eligibility declaration. ${ }^{169}$ The Council may adopt directives establishing cooperation and coordination measures necessary to facilitate diplomatic and consular protection. ${ }^{170}$ The legislature is obliged to adopt provisions for procedures and conditions required for the citizens' initiative, as it has already done by adopting Regulation No. 211/2011. ${ }^{171}$

The right to vote is a key political right that requires further consideration by the legislature. At the moment, non-national EU citizens residing in member states cannot vote in national elections as Article 20(2)(b) TFEU only provides for the right to vote in municipal and European Parliament elections. ${ }^{172}$ This curtails the level of democratic participation in their country of residence even when the individual has lived there for an extended period of time, perhaps establishing professional, personal, and social ties. Double votingnamely, voting in the country of nationality as well as the country of residence-is

${ }^{164}$ See id. art. 18.

${ }^{165}$ See id. art. 19(1).

${ }^{166}$ See id. art. 21(2).

${ }^{167}$ See id. art. 46. See also id. arts. 21(3), 48 (enumerating Council powers for social security).

${ }^{168}$ See id. arts. 22(1)-22(2).

${ }^{169}$ See Council Directive No. 2013/1/EU, of 20 December 2012 Amending Directive 93/109/EC as Regards Certain Detailed Arrangements for the Exercise of the Right to Stand as a Candidate in Elections to the European Parliament for Citizens of the Union Residing in a Member State of Which They Are Not Nationals, 2012 O.J. (L 26), 27.

${ }^{170}$ See TFEU art. 23.

${ }^{171}$ See Commission Regulation No. 211/2011, 2011 O.J. (L 65).

${ }^{172}$ See TFEU art. 20(2)(b). 
prevented under the assumption that individuals retain the right to vote in their country of nationality. But it may cause double jeopardy as Malta, Cyprus, Denmark, the UK, and Ireland apply disenfranchisement policies to nationals residing in other member states. ${ }^{173}$ Without the right to vote in the country of residence, EU citizens would be denied a fundamental political right by virtue of exercising their right to free movement. This raises interesting questions about member state control over nationality, the substance of EU citizenship, and whether there is a right of choice.

On the one hand, member states have discretion to determine nationality criteria, which may include the need to show a strong and continuing link with the country of nationality to benefit from national voting rights. On the other hand, political rights are fundamental to EU citizenship enabling democratic participation at the local, regional, national, and EU level. A person's nationality is not weakened or removed when they reside in another member state. If this were the case, it would undermine the principle of nondiscrimination and allow disparity of rights throughout the EU with a notion of diminished citizenship. Arguably, the non-resident national may maintain stronger political ties to the country of nationality than a resident national. The former may actively seek to maintain the right to vote, whereas the latter may or may not be politically engaged by, for example, choosing not to vote. The reverse may also apply. A non-resident national may establish stronger political ties in the country of residence and therefore wish to vote in national elections there. A right of choice between voting in the country of nationality or country of residence would prevent double voting and double jeopardy. This offers a solution to public opinion supportive of maintaining the right to vote in the country of nationality, and having a right to vote in the country of residence. ${ }^{174}$ The Commission identified this as an area for strengthening citizenship rights under Article 25 TFEU, and recently recommended discontinuation of disenfranchisement policies to allow citizens the right to vote if they can demonstrate "a continuing interest in the political life in their country."

\footnotetext{
${ }^{173}$ See R (on the application of James Alistair Preston) v. Lord President of the Council, [2012] EWCA (Civ) 1378, [2013] Q.B. 687 (Eng.) (rejecting a UK national's right to vote after living in Spain for over 15 years). See also Parliamentary Election Act of Denmark, 2009, pt. 1(2)(3) (allowing Danish citizens leaving the country to remain on the electoral roll only if they have registered their intention to return within two years).

${ }^{174}$ In 2013, sixty-five percent of EU citizens favored not losing the right to vote in the citizen's country of nationality; sixty-seven percent favored non-national EU citizens having the right to vote in the citizen's country of residence. See EU Citizenship Report 2013, supra note 132, at 21-22.

175 See id. at 24; Commission Recommendation No. 2014/53/EU of 29 January 2014, Addressing the Consequences of Disenfranchisement of Union Citizens Exercising Their Rights to Free Movement, 2014 O.J. (L 32) 34.
} 


\section{National Parliaments' Pre-Legislative Controls}

The democratic principles listed in Title II of the TEU include involvement of national parliaments. Article 12 TEU identifies a number of ways in which national parliaments "contribute actively to the good functioning of the Union": Reviewing draft legislative acts; guarding subsidiarity; participating in treaty revision procedures; participating in interparliamentary cooperation between national parliaments and the European Parliament; notification of accession applications; evaluating policies in the area of freedom, security, and justice; monitoring Europol; and evaluating Eurojust. ${ }^{176}$ Protocol (No. 1) on the Role of National Parliaments in the European Union ("Protocol No. 1") is intended to encourage greater involvement of national parliaments in EU activities and enhance their ability to express views on draft legislative acts and other matters. ${ }^{177}$ National parliaments enjoy the support and consent of EU citizens providing accountability for these functions. They have three treaty-based roles that can act as powerful pre-legislative controls on EU decisionmaking: scrutinizing legislation; guarding subsidiarity; and exercising veto powers.

\section{Informed Scrutinizers}

Article 12(a) TEU provides that national parliaments contribute actively to the good functioning of the EU by being informed and receiving draft legislative acts. ${ }^{178}$ In this regard, EU institutions are obliged to provide the following information: (1) Commission consultation documents, annual legislative programs, and any other instrument of legislative planning or policy; (2) draft legislative acts-including Commission proposals, initiatives from a group of member states, initiatives from the European Parliament, requests from the CJEU, recommendations from the European Central Bank, and requests from the European Investment Bank; (3) agendas for the outcome of Council meetings, including minutes of meetings on draft legislative acts; and (4) Court of Auditors annual report. ${ }^{179}$ Once received, it is a matter for each parliament to decide how to scrutinize and whether to comment on proposals, especially draft legislative acts. It does, nevertheless, require a proactive approach in assuming the role of scrutinizer and setting up scrutiny mechanisms, rather than acting as a mere repository. ${ }^{180}$ In this sense, national parliaments

\footnotetext{
${ }^{176}$ See TEU art. 12.

${ }^{177}$ See id. protocol no. 1.

${ }^{178}$ See id. art. 12(a).

${ }^{179}$ See id. protocol no. 1., arts. 1, 2, 5, 7.

${ }^{180}$ For a "holistic approach" to EU lawmaking and implementation involving active and responsible involvement by national institutions see Piqani, supra note 8 , at 493 . National court decisions have called for greater involvement of legislatures in scrutinizing EU legislation and as guardians of the balance of power between
} 
take the role of informed scrutinizers, participating in EU decision-making early on to check for potential conflicts with domestic law and to maintain the balance of power between the EU and member states.

The inter-parliamentary cooperation system under Protocol No. 1 encourages dialogue between national parliaments and the European Parliament, allowing the former to collectively submit "contributions" for consideration by the European Parliament, the Council, and the Commission. ${ }^{181}$ These contributions are not binding on national parliaments and do not prejudice their positions. They are an opportunity for exchange of information, agenda setting, and policy coordination. The 2006 Barroso Initiative was launched to enable political dialogue between the European Parliament and national parliaments. ${ }^{182}$ In practice, it has enabled national parliaments to obtain draft legislative acts directly from the Commission and then to submit their opinions. This improves vertical political dialogue with the EU, but there is concern it is not having a similar impact on horizontal political dialogue between national parliaments. ${ }^{183}$

While treaty provisions do not specifically state that national parliaments must act as informed scrutinizers, it would be counter-productive for democratically-elected representatives not to take up this opportunity as a means to ensure transparency and accountability in decision-making. Depending on the resources available, political interests, and importance placed on scrutiny, each parliament's role and level of scrutiny will vary. ${ }^{184}$ It demonstrates how EU decision-making is based on "multi-levelled democratic

member states and the EU. See Ústavní soud České republiky ze dne 26.11 .2008 (ÚS) [Decision of the Constitutional Court of Nov. 26, 2008], sp.zn. PI. ÚS 19/08, para. 165 (Czech); Bundesverfassungsgericht [BVerfG Federal Constitutional Court], Case No. 2BvE 2/08, para. 409 (June 30, 2009), https://www.bundesverfassungsgericht.de/entscheidungen/es20090630_2bve000208en.html.

${ }^{181}$ See TEU protocol no. 1.

${ }^{182}$ See European Commission, A Citizens' Agenda: Delivering Results for Europe, at 9, COM (2006) 211 final (May 10, 2006).

183 Adam Cygan, The Parliamentarisation of EU DecisionMaking? The Impact of the Treaty of Lisbon on National Parliaments, 36 EUR. L. ReV. 480, 494-95 (2011).

${ }^{184}$ See European Commission, Annual Report 2012 on Subsidiarity and Proportionality, at 3, COM (2013) 566 final (July 30, 2013) [hereinafter Annual Report 2012]; AdAM CygAN, THE UK PARLIAMENT AND EUROPEAN UNION LEGISLATION ch. 3 (1998); Klaus Goetz \& Jan-Hinrik Meyer-Sahling, The Europeanisation of National Political Systems: Parliaments and Executives, 3 LIVING REV. EUR. Gov. (2008), http: / /europeangovernance.livingreviews.org/Articles/lreg-2008-2/download//reg-2008-2Color.pdf; Philipp Kilver, The National Parliaments in the European Union: A CRitical View on EU Constitution Building 162-63 (2006). 
legitimation" and the potential for elected representatives to make the EU accountable. ${ }^{185}$ National parliaments acting as informed scrutinizers offer a degree of accountability and help shape public understanding of how the EU operates.

\section{Guardians of Subsidiarity}

Article 12(b) TEU provides that national parliaments contribute actively to the good functioning of the EU by acting as guardians of subsidiarity. ${ }^{186}$ This role is exercised in relation to the principle of subsidiarity under Article 5(3) TEU and the early warning system under Protocol No. 2. ${ }^{187}$ Except for exclusive competence areas, subsidiarity applies to all shared or supported competence decisions. It determines at which level decisions should be made when there are multiple levels of decision-making authority-for example, local, regional, national, or supranational. In accordance with the Preamble and Article 1 paragraph 2 TEU and the Preamble to Protocol No. 2, decisions should be taken as closely as possible to EU citizens, reinforcing the idea of democratic accountability. ${ }^{188}$

\section{Two-Stage Test for Subsidiarity}

Article 5(3) TEU provides a two-stage test of necessity and effectiveness for subsidiarity: EU action must be necessary because the proposed action's objectives cannot be sufficiently achieved by member states; and, due to the scale or effects of the proposed action, the objectives would be more effectively achieved by the EU. ${ }^{189}$ "Multi-leveled democratic legitimation" is apparent with involvement of EU institutions and national parliaments. ${ }^{190}$ Decisions by EU institutions must take into account subsidiarity and demonstrate both how objectives for a proposed action cannot be sufficiently achieved by member states, and the extent or results of the proposed action means it is better achieved by the EU. This conforms with the requirement under Article 5 Protocol No. 2 for

\footnotetext{
${ }^{185}$ Mattias Wendel, Lisbon Before the Courts: Comparative Perspectives, 7 EUR. CONST. L. REV. 96,117 (2011). See also Ústavní soud České republiky ze dne 26.11.2008 (ÚS) [Decision of the Constitutional Court of Nov. 26, 2008], sp.zn. Pl. ÚS 19/08, para. 173 (Czech); Ústavní soud České republiky ze dne 03.11.2009 (ÚS) [Decision of the Constitutional Court of Nov. 3, 2009], sp.zn. Pl. ÚS 29/09, para. 138.

${ }^{186}$ See TEU art. 12(b).

${ }^{187}$ See id. art. 5(3); id. protocol no. 2.

${ }^{188}$ See id. Preamble; id. art. 1; id. protocol no. 2, Preamble.

${ }^{189}$ See European Commission, On Subsidiarity and Proportionality, at 2, COM (2008) 586 final (Sept. 26, 2008). For a single test approach, see Derrick Wyatt, Could a Yellow Card for National Parliaments Strengthen Judicial as Well as Political Policing of Subsidiarity, 2 CROATIAN Y.B. EUR. L. \& POL’Y 1, (2006).

${ }^{190}$ Wendel, supra note 185 , at 117.
} 
subsidiarity appraisal of draft legislative acts, and the oversight role entrusted to national parliaments under Article $6 .^{191}$

Necessity and effectiveness must both be satisfied so that EU action may be a matter of degree rather than absoluteness. Member states' action in a shared competence area may prove insufficient to tackle a cross-border dimension. An example is the 2012 Commission Proposal for a Regulation on the Right to Collective Strike ("Monti II Regulation") intended to tackle cross-border dimensions to the right to collective action in relation to the freedom of establishment and the freedom to provide services. ${ }^{192}$

Member states and the EU have applied the test differently. There is a debate around a broad interpretation with a presumption against EU action and a restrictive interpretation in accordance with necessity and effectiveness without reference to proportionality. ${ }^{193}$ Treaty provisions support the latter approach where national parliaments are granted an oversight role only for subsidiarity and not proportionality, which is a matter for EU institutions to apply. Based on the Commission's 2012 Report, national parliaments regard subsidiarity as a legal principle subject to different interpretations and outcomes. ${ }^{194}$ The Commission published its own practice in applying standard criteria as guidance for national parliaments. ${ }^{195}$ While recognizing the benefit of having standard compliance criteria, national parliaments want to maintain a margin of discretion. Political opportunism may influence subsidiarity monitoring to the detriment of a more strict application of the two-stage test to focus on the merits of a proposed legislative act. ${ }^{196}$

${ }^{191}$ See TEU protocol no. 2, arts. 5-6.

192 Proposal for a Council Regulation on the Exercise of the Right to Take Collective Action Within the Context of the Freedom of Establishment and the Freedom to Provide Services, at 8, COM (2012) 130 final (Mar. 21, 2012). For the background to this proposal, see Mario Monti, A New Strategy for the Single Market (May 9, 2010), http://ec.europa.eu/internal_market/strategy/docs/monti_report_final_10_05_2010_en.pdf;

European Commission, Towards a Single Market Act: For a Highly Competitive Social Market Economy, COM (2010) 623 (Oct. 27, 2010).

${ }^{193}$ For

a restrictive interpretation, see Federico Fabbrini \& Katarzyna Granat, Yellow Card, But No Foul: The Role of the National Parliaments Under the Subsidiarity Protocol and the Commission Proposal for an EU Regulation on the Right to Strike, 50 Cомmon Mкт. L. REV. 115 (2013). For a broad interpretation, see Gareth Davies, Subsidiarity: The Wrong Idea, in the Wrong Place, at the Wrong Time, 43 Common MкT. L. Rev. 63 (2006); Jukka Snell, 'European Constitutional Settlement,' an Ever Closer Union, and the Treaty of Lisbon: Democracy or Relevance?, 33 EUR. L. REV. 619, 627-30 (2008)

${ }^{194}$ See Annual Report 2012, supra note 184.

${ }^{195}$ See id. at 3-4, 10. For Commission criteria, see Commission Impact Assessment Guidelines, SEC (2009) 92 (Jan. $15,2009)$.

196 See Jit Peters, National Parliaments and Subsidiarity: Think Twice, 1 EUR. CONST. L. REV. 68, 71 (2005). 
Nevertheless, if exercised properly, subsidiarity monitoring under the early warning system offers national parliaments a pre-legislative control over decision-making.

\section{The Early Warning System}

The early warning system ("EWS"), under which national parliaments monitor subsidiarity compliance, is established by Protocol No. 2 with two distinct procedures: The "yellow card" procedure, under Article 7(2), obliges review of draft legislation deemed noncompliant by national parliaments; and the "orange card" procedure, under Article 7(3), obliges review and, under certain conditions, withdrawal of the proposal. ${ }^{197}$ When an EU institution proposes a draft legislative act, this must be forwarded to all national parliaments with a detailed statement of the following: Compliance with subsidiarity and proportionality; assessment of financial impact; in the case of directives, implications for rules to be put in place by member states, including regional legislation; reasons for concluding that an EU objective can be better achieved at EU level, with qualitative and, where possible, quantitative indicators; and how any financial or administrative burden on the EU, national governments, regional or local authorities, economic operators, and citizens will be minimized and commensurate with the objective to be achieved. ${ }^{198}$

National parliaments have eight weeks to scrutinize the draft legislative act, affording a degree of pre-legislative control over EU decision-making. During this period, the Council is not permitted to place the draft legislative act on its provisional agenda for adoption. After eight weeks, an additional period of ten days must elapse between placing the draft legislative act on the Council's provisional agenda and the adoption of a position. In an urgent case where a draft legislative act needs to be agreed upon within the eight-week period, the Council must give reasons for its position. ${ }^{199}$ If a national parliament considers the draft act does not comply with subsidiarity, it must submit a "reasoned opinion" to the Presidents of the European Parliament, the Council, or Commission, depending on who initiated the draft.

Unlike the detailed statement attached to draft legislative acts, national parliaments are not required to provide a detailed explanation in their reasoned opinions. A statement of why the draft legislative act does not comply with subsidiarity will suffice. ${ }^{200}$ Reasoned

\footnotetext{
${ }^{197}$ See TEU protocol no. 2, arts. 7(2)-7(3).

${ }^{198}$ See id. protocol no. 2, arts. 4-5.

${ }^{199}$ See id. protocol no. 1, arts. 3-4.

${ }^{200}$ See id. protocol no. 2, art. 2.
} 
opinions can vary in substantive content and interpretation of subsidiarity. ${ }^{201}$ Such a wide margin of discretion counters arguments about the weakness of subsidiarity monitoringnamely, lack of resources or adequate time to consider proposals. It may also help foster horizontal political dialogue between national parliaments to coordinate their responses. $^{202}$ Some may be reluctant to challenge their government's position with a perceived lack of electoral benefit in doing so. ${ }^{203}$ But this is a matter for member states' domestic accountability systems, which would exist irrespective of the opportunity to act as guardians of subsidiarity.

\subsection{Obligation to Review}

Under the yellow card procedure, reasoned opinions count as votes and, if one third of all national parliaments' votes conclude the draft legislation is non-compliant with subsidiarity, the initiating institution must review it. For draft legislative acts submitted under Article 76 TFEU on the area of freedom, security, and justice, the review threshold is one quarter of all national parliaments' votes. ${ }^{204}$ The initiating body "may decide to maintain, amend, or withdraw" the draft legislation. ${ }^{205}$ There is no obligation for it to be withdrawn, but reasons must be given for any decision, ensuring accountability through transparent and open decision-making.

This procedure was used for the first time in 2012 in relation to the Monti II Regulation with twelve reasoned opinions from national parliaments, representing nineteen votes, against the Commission's proposal. ${ }^{206}$ The Commission had consulted widely with relevant stakeholders and provided a detailed statement of subsidiarity compliance. But national parliaments considered the proposal did not comply with subsidiarity with reasons ranging from the legal basis of the proposal under Article 352 TFEU to non-compliance with

\footnotetext{
${ }^{201}$ For an analysis of variation in reasoned opinions in the Proposed Monti II Regulation, see Fabbrini \& Granat, supra note 193 , at 115.

202 See Cygan, supra note 183, at 484.

203 See lan Cooper, A 'Virtual Third Chamber' for the European Union? National Parliaments After the Treaty of Lisbon 10 (Centre for European Studies, ARENA Working Paper No. 7, 2011). For example, in 2015 the opposition Labour Party in the UK backed down from its original position not to hold an EU membership referendum, due to perceived public appetite for a referendum and the government's intention to hold one. See Labour to Back EU Referendum Bill, Says Harman, BBC (May 24, 2015), http: //www.bbc.co.uk/news/uk-politics-32863749.

${ }^{204}$ See TEU protocol no. 2, art. 7(2).

205 See id.

${ }^{206}$ See Annual Report 2012, supra note 184, at 6-7.
} 
proportionality. ${ }^{207}$ The Commission reviewed the proposal but found no breach of subsidiarity. In a remarkable concession to political accountability, it "took note of the views expressed by national parliaments" and recognized that the draft regulation "was unlikely to gather the necessary political support within the European Parliament and Council to enable adoption." ${ }^{208}$ The Commission withdrew the Monti II Regulation on 26 September 2012. ${ }^{209}$ This shows that simply attaining the review threshold can exert political influence. Even then, if the institution finds compliance with subsidiarity, pursuing legislation may be unwise if it is likely to encounter member state resistance. Some argue this sets a bad precedent for misuse of subsidiarity monitoring as the Commission found no breach of subsidiarity. ${ }^{210}$ But it reflects how national parliaments act as pre-legislative filters testing political appetite before the Council and European Parliament make a decision.

Representing a cross-section of society with a mandate to probe legislation in the wider public interest, parliamentarians engage in information-gathering, debates, deliberations, and in-depth reports or inquiries. These activities legitimize the decision-making process by being receptive to opposing views, competing interests, appraisal of socio-economic impacts, and consultation with relevant stakeholders. ${ }^{211}$ In this sense, the filtering role is constitutionally protected in member states, ${ }^{212}$ and a legitimate form of democratic accountability is provided under the Treaties.

\footnotetext{
${ }^{207}$ See TFEU art. 352. For detailed analysis of reasoned opinions, see Fabbrini, supra note 193, at 115.

${ }^{208}$ Annual Report 2012, supra note 184, at 8.

${ }^{209}$ See id.

${ }^{210}$ See Fabbrini \& Granat, supra note 193, at 115.

${ }^{211}$ See cases on parliamentarians' access to information. See, e.g., Case C-350/12P, Council v. in 't Veld (July 3, 2013), http://curia.europa.eu; C-280/11P, Council v. Access Info Europe (Oct. 17, 2013), http://curia.europa.eu.

${ }^{212}$ For the German Constitutional Court's development of the concept of parliamentary responsibility owed to the people, see Bundesverfassungsgericht [BVerfG - Federal Constitutional Court], Case No. 2BvE 2/08, paras. 210, 243, 246-60 (June 2009), https://www.bundesverfassungsgericht.de/entscheidungen/es20090630_2bve000208en.html. For the UK House of Lords, scrutinizing, influencing, and holding national governments accountable should be recognized as "core business" for national parliaments. See EUROPEAN UNION COMMITTEE, THE Role of NATIONAL PARLIAMENTS IN THE EUROPEAN UNION, 2013-14, H.L. 151, at 11 (U.K.).
} 


\subsection{Obligation to Withdraw}

The orange card procedure relates to Commission proposals for legislation under the ordinary legislative procedure. Where a simple majority of votes of national parliaments find non-compliance with subsidiarity, the Commission must review the proposal. Similar to the yellow card, the Commission "may decide to maintain, amend or withdraw" it. ${ }^{213}$ Unlike the yellow card, however, if the Commission decides to keep the proposal, it will have to justify that proposal in a reasoned opinion which, along with national parliaments' reasoned opinions, must be submitted to the European Parliament and the Council. They must then follow a two-stage process: First, reviewing subsidiarity compliance while taking into account reasoned opinions of national parliaments and the Commission; and second, withdrawing the proposal if either institution decides by a threshold number-fifty-five percent of Council members or a majority of votes in the European Parliament-that the proposal is non-compliant. ${ }^{214}$

One criticism leveled against the EWS is that it does not have a "red card" procedure, effectively a veto power, for national parliaments. ${ }^{215}$ The Working Group IV on the Role of National Parliaments, however, focused on ensuring effective early participation in scrutiny of legislation rather than setting up mechanisms for legislative delays. Constitutionally, national parliaments are not part of the EU legislature and the Working Group was concerned to maintain institutional balance. ${ }^{216} \mathrm{~A}$ veto power could frustrate decisionmaking without adding any value to its effectiveness at the appropriate level. It may also exacerbate weak monitoring due to lack of time and resources. More stringent scrutiny requirements, including those for reasoned opinions, would be necessary to counter positions of the Council and the European Parliament in order to prevent legislation passing, potentially affecting the separation of powers within member states.

\section{Veto Powers}

National parliaments have an accountability brake, effectively a veto, under Article 48(7) $\mathrm{TEU}$, the passerelle clause. ${ }^{217}$ Under this clause the European Council may adopt a decision

\footnotetext{
${ }^{213}$ See TEU protocol no. 2, art. 7(3).

${ }^{214}$ See id. art. 7(3)(a)-(b).

215 European SCRUtiny CommitTEe, Subsidiarity, NATIONAL PARLIAMENTS AND THE Lisbon TreATY, 2007-8, H.C. 563, para. 36 (U.K.).

${ }^{216}$ Council of Europe Working Group IV, Final Report of Working Group IV on the Role of national Parliaments, CONV 353/02, paras. 21-26, 33 (Oct. 22, 2002).

${ }^{217}$ See TEU art. 48(7).
} 
authorizing the Council of Ministers to act by qualified majority voting instead of unanimity, or under the ordinary legislative procedure instead of a special legislative procedure. ${ }^{218}$ But the European Council is obliged to inform national parliaments at least six months before any such decision is adopted. ${ }^{219}$ If, within this period, a single national parliament makes known its opposition, the decision will not be adopted. Thus, any national parliament of a member state, acting on its own, can veto changes to voting procedures. They are not obliged to exercise this veto, and, in the absence of any opposition, the European Council may adopt the decision. An active, well-informed, and democratically-engaged parliament, however, should at least be aware of this power and its potential as a mechanism to hold EU institutions accountable for how they make decisions. The European Council does not exercise legislative functions and is a political body composed of heads of state or governments of member states that sets the EU's political directions and priorities. ${ }^{220}$ In this respect, for national parliaments, being informed about vetoing voting procedure changes is a step toward holding prime ministers and presidents accountable for how they make decisions at this level.

Another veto power of national parliaments relates to the area of freedom, security, and justice. Specifically in relation to aspects of family law with cross-border implications, the Commission may propose the Council of Ministers adopt a decision to determine which aspects may be the subject of acts adopted under the ordinary legislative procedure. Before any decision is taken, however, national parliaments must be notified of such a proposal and if a single national parliament opposes within six months of receiving the notification, the decision is not adopted. ${ }^{221}$ As with Article 48(7) TEU, exercise of the veto does not require acting in concert with others; one parliament's opposition is enough for the decision to fail. ${ }^{222}$ The difference with this provision is that it actually involves national parliaments deciding on a competence issue, albeit a limited one relating to cross-border family law matters, rather than voting procedures. In exercising this power, national parliaments review whether a given family law matter should come under supranational decision-making. A seemingly discrete area of law could attract high levels of public interest on issues such as child abduction, protection of children's rights, and even mutual recognition of same-sex relationships, which would all require cooperation between member states. Equally, aspects of family law may be too sensitive and form part of

\footnotetext{
${ }^{218}$ Art. 294 TFEU sets out the procedure that involves the European Parliament.

${ }^{219}$ See TEU protocol no. 1, art. 6.

${ }^{220}$ See id. art. 15.

${ }^{221}$ See TFEU art. 81(3)

${ }^{222}$ See TEU art. 48(7).
} 
national identity such that member states will want to maintain their decision-making autonomy.

\section{E. Conclusion}

EU treaties are international treaties by which member states agree to be bound once they formalize national consent through ratification. Both at the candidate stage and throughout membership, states are obliged to implement legislation and amend laws to comply with EU law. Member states have used a range of domestic pre-legislative controls on consent, especially as regards membership enlargement or major treaty revisions. Prior parliamentary approval, either in the form of statute enactment or formal vote, is the most prevalent form of pre-legislative control. Even in Germany and Poland, with an advanced understanding of democratic participation and constitutional provisions on referendums respectively, referendums are still not invoked as a pervasive pre-legislative control.

By contrast, the UK's EU Act makes future EU law not only subject to parliamentary approval, but also to a referendum. Such extensive use of referendums is a clumsy brake on internal voting procedures, hindering efficient decision-making and representing a hollow sense of empowerment for citizens. Voting on technical areas can lead to voter apathy, low turnouts, and further distancing the public from EU matters. It is far more important to hold governments and EU institutions accountable by granting the public access to information on government voting positions and their basis, while still giving the public a right to vote on more substantive matters. Ironically, the UK is precipitating a wider democratic deficit in the EU by effectively vetoing the opportunity for other member states to progress towards further integration. This is counterproductive as it raises doubts about the UK's ability to act in good faith, leading to isolation and loss of the credibility to influence decision-making. Alternatively, the other twenty-seven member states could decide to develop closer integration measures excluding the UK so that EU decision-making is not adversely affected.

Constitutional principles of citizenship, democracy, and political rights further democratic accountability. Supranational decision-making is based on a representative democracy with direct and indirect accountability to citizens in member states. The right to participate in the democratic life of the EU and democratic principles of transparency and open decisionmaking make this possible. However, recent examples of citizen-based initiatives under Article 11(4) TEU illustrate the limitations of popular vote decision-making where there is lack of understanding of EU law and potential for initiatives to be hijacked by narrow political interests. ${ }^{223}$ Of far greater significance is the CJEU's recognition that effective participation in the political life of the EU includes the right of citizens and national

${ }^{223}$ See id. art. 11(4). 
parliamentarians to access information regarding member states' negotiating positions and proposals for legislative amendments. The EU's protector role in upholding rights, especially through the Commission's oversight responsibilities and the legislative functions of the European Parliament and the Council, justifies supranational decision-making. An internal system of accountability exists with the European Parliament and the Council of Ministers approving the Commission's legislative proposals.

It is in the area of scrutinizing draft legislative acts and proposals that national parliaments can have the greatest impact on accountability. Representing one of the few mechanisms for direct accountability to elected representatives of member states, subsidiarity monitoring under the EWS is a powerful pre-legislative control with the potential to block legislation. Member states' approach to the subsidiarity test varies, as does the substance of their reasoned opinions. But this is partly due to lack of uniform scrutiny requirements, and a desire to maintain a margin of discretion. Defeat of the proposed Monti II Regulation shows what can be achieved when national parliaments coordinate reasoned opinions, and act as filters testing political appetite for new legislation. Representing a cross-section of society with a mandate to probe legislation in the wider public interest, parliamentarians engaged in a variety of scrutiny activities legitimize the decision-making process, thus fulfilling a national constitutional and treaty-based role. 